\title{
Aloe-emodin as drug candidate for cancer therapy
}

Research Paper

\author{
Nadire Özenver ${ }^{1}$, Mohamed Saeed ${ }^{2}$, Lütfiye Ömur Demirezer ${ }^{1}$ and Thomas Efferth ${ }^{2}$ \\ ${ }^{1}$ Department of Pharmacognosy, Faculty of Pharmacy, Hacettepe University, 06100 Ankara, Turkey \\ ${ }^{2}$ Department of Pharmaceutical Biology, Institute of Pharmacy and Biochemistry, Johannes Gutenberg University, 55128 \\ Mainz, Germany \\ Correspondence to: Thomas Efferth, email: efferth@uni-mainz.de \\ Keywords: Aloe-emodin; Rumex acetosella; cancer; multi-drug resistance; anthraquinone \\ Received: June 27, $2017 \quad$ Accepted: February 27, $2018 \quad$ Published: April 03, 2018 \\ Copyright: Özenver et al. This is an open-access article distributed under the terms of the Creative Commons Attribution License \\ 3.0 (CC BY 3.0), which permits unrestricted use, distribution, and reproduction in any medium, provided the original author and \\ source are credited.
}

\section{ABSTRACT}

As a leading cause of global mortality, cancer frequently cannot be cured due to the development of drug resistance. Therefore, novel drugs are required. Naturally occurring anthraquinones are mostly present in Rumex and Rhamnus species and are of interest because of their structural similarity to anthracyclines as well established anticancer drugs. In the present study, we focused on the structural elucidation of phytochemicals from $R$. acetosella as well as the investigation of cytotoxicity and modes of action of the main anthraquinone aglycons (emodin, Aloe-emodin, physcion, rhein). Resazurin reduction and protease viability marker assays were conducted to test their cytotoxicity. Microarray-based gene expression profiling was performed to identify cellular pathways affected by the compounds, which was validated by qPCR analyses and functional assays. Flow cytometry was used to measure cell cycle distribution, apoptosis and necrosis, induction of reactive oxygen species (ROS) and disruption of mitochondrial membrane potential (MMP). The comet assay was used to detect DNA damage. Aloe-emodin as the most cytotoxic compound revealed IC $_{50}$ values from $9.872 \mu \mathrm{M}$ to $22.3 \mu \mathrm{M}$ in drug-sensitive wild-type cell lines and from $\mathbf{1 1 . 1 9}$ $\mu \mathrm{M}$ to $33.76 \mu \mathrm{M}$ in drug-resistant sublines, was selected to investigate its mechanism against cancer. Aloe-emodin-induced $S$ phase arrest, ROS generation, DNA damage and apoptosis. Microarray hybridization revealed a profile of deregulated genes in Aloe-emodin-treated CCRF-CEM cells with diverse functions such as cell death and survival, cellular growth and proliferation, cellular development, gene expression, cellular function and maintenance. Aloe-emodin as well as $R$. acetosella deserve further investigations as possible antineoplastic drug candidates.

\section{INTRODUCTION}

Cancer is one of the leading cause of death worldwide. In 2012, 14.1 Mio people were diagnosed with cancer [1] and new cases with cancer is predicted to ascend by $70 \%$ over the next 20 years [2].

Despite notable improvements in cancer research in the past few decades, many cancer patients still cannot be cured due to the development of drug resistance. Even worse, tumors frequently develop resistance not only to single drugs, but also towards many drugs at the same time. This phenomenon was termed multidrug resistance and decreases the success of chemotherapy [3]. The response of tumor cells to cytotoxic agents is frequently determined by multiple factors $[4,5]$.

Natural sources might have importance as potential drug candidates. Evidently, $69 \%$ of anticancer drugs approved between the 1980s and 2002 were either natural products or developed based on knowledge gained from natural substances [6]. Natural compounds are indispensable not only as chemically established anticancer drugs (e.g. anthracyclines, Vinca alkaloids, taxanes, camptothecins 
etc.), but also as lead compounds for the development of novel targeted chemotherapeutics with improved antitumor efficacy and fewer side effects [7].

Among the various chemical classes of natural products, anthraquinones are characterized by their large structural diversity, pronounced biological activity and low toxicity [8]. Anthraquinones are mostly present in the families of Fabaceae (Cassia), Liliaceae (Aloe), Polygonaceae (Rumex), Rhamnaceae (Rhamnus), Rubiaceae (Asperula, Gallium,Rubia), and Scrophulariaceae [9]. Anthraquinones inhibited growth of tumor cell lines derived from breast [10-12], lung [11], cervix [13], prostate [14], colon, central nervous system as well as of glioma [11, 15], hepatoma [16] and leukemia $[17,18]$. Furthermore, the structural similarity of anthraquinone aglycons to anthracyclines as well established anticancer drugs allows to speculate on their possible activities against cancer.

Rumex acetosella L. (Polygonaceae) has a long tradition in folk medicine for cancer treatment [19-21], e.g. as component of Essiac tea in Canada [22]. The traditional use of $R$. acetosella extracts was substantiated by in vitro studies [23]. The plant contains anthraquinones, flavonoids and other phenolics [21, 24, 25, 26]. The constituents of the plant may account for its cytotoxicity.

In the present investigation, we focused on the cytotoxic effects of the main anthraquinone aglycons (emodin, Aloe-emodin, physcion, rhein) against cancer cells. The aims of the present study were:

(1) The structural elucidation of phytochemicals from $R$. acetosella and

(2) The identification of cellular and molecular factors determining cytotoxicity and acquired resistance. Aloe-emodin was selected from the panel of compounds in $R$. acetosella. Upon treatment of cells with Aloe-emodin, microarray-based expression profiles, reactive oxygen species (ROS), DNA damage, cell cycle arrest, as well as apoptosis and necrosis were investigated.

(3) Since tumor cells can be unresponsive to cytotoxic compounds, even if they have never been exposed to drugs before, we also studied factors of inherent resistance to Aloe-emodin by microarray-based mRNA profiling.

\section{RESULTS}

\section{Structural determination of the isolated phytochemicals}

The structures of isolated compounds were elucidated with spectroscopic data. The compounds belonged to the phytochemical classes of anthraquinones, naphthalenes, stilbenoids, lignins, ethanones or tannins (Figure 1).

In addition to known substances, we isolated a new glycoside (compound 2) from the roots of $R$. acetosella and named it acetoselloside.
Compound 1: (E)-Piceid.

${ }^{1} \mathrm{H}$ NMR (600 MHz, DMSO-d $) \delta 9.56$ (s, 1H, C-4“"$\mathrm{OH}), 9.49$ (s, 1H, C-3-OH), $7.42-7.37$ (m, 2H, H-2“", H-6“) 7.03 (d, $\left.J=16.3 \mathrm{~Hz}, 1 \mathrm{H}, \mathrm{H}-2^{\circ}\right), 6.86$ (d, $J=16.3$ $\mathrm{Hz}, 1 \mathrm{H}, \mathrm{H}-1^{\circ}$ ) , $6.78-6.73$ (m, 2H, H-3“" H-5 “) 6.72 (t, $J$ $=1.8 \mathrm{~Hz}, 1 \mathrm{H}, \mathrm{H}-6), 6.55(\mathrm{t}, J=1.8 \mathrm{~Hz}, 1 \mathrm{H}, \mathrm{H}-4), 6.32(\mathrm{t}$, $J=1.8 \mathrm{~Hz}, 1 \mathrm{H}, \mathrm{H}-2), 5.29$ (d, $J=4.8 \mathrm{~Hz}, 1 \mathrm{H}, \mathrm{C}-2$ ““”-OH), 5.11 (s, 1H, C-3“"“-OH), 5.04 (s, 1H, C-4““-OH), 4.79 (d, $J$ $=7.7 \mathrm{~Hz}, 1 \mathrm{H}, \mathrm{H}-1$ ““'), 4.64 (t, $J=5.8 \mathrm{~Hz}, 1 \mathrm{H}, \mathrm{C}-6$ “"“-OH), 3.72 (ddd, $J=11.8,5.8,2.1 \mathrm{~Hz}, 1 \mathrm{H}, \mathrm{H}-6$ “" $), 3.48$ (dt, $J=$ $11.8,5.8 \mathrm{~Hz}, 1 \mathrm{H}, \mathrm{H}-6^{\text {“" })}$ ) 3.31 (ddd, $J=9.4,5.8,2.1 \mathrm{~Hz}$, $\left.1 \mathrm{H}, \mathrm{H}-5^{\prime \prime c}\right), 3.26$ (t, $\left.J=8.9 \mathrm{~Hz}, 1 \mathrm{H}, \mathrm{H}-3{ }^{\text {“c }}\right), 3.20$ (td, $J=$ 8.4, 4.8 Hz, 1H, H-2““) 3.15 (t, $J=9.4 \mathrm{~Hz}, 1 \mathrm{H}, \mathrm{H}-4$ “" $)$.

${ }^{13} \mathrm{C}$ NMR (151 MHz, DMSO) $\delta 158.9$ (C-1), 158.4 (C-3), 157.4 (C-4“"), 139.4 (C-5), 128.6 (C-2‘), 128.0 (C$2^{\text {“" }, ~ C-6 “), ~} 125.2\left(\mathrm{C}-1^{\circ}\right), 115.6\left(\mathrm{C}-3^{\circ}\right.$,, $\left.\mathrm{C}-5^{\circ 6}\right), 107.2(\mathrm{C}-4)$, 104.7 (C-6), 102.7 (C-2), 100.7 (C-1““), 77.2 (C-5““), 76.7 $\left(\mathrm{C}-3^{\text {cc }}\right), 73.3\left(\mathrm{C}-2^{6 / 6}\right), 69.8\left(\mathrm{C}-4^{6 / 6}\right), 60.7$ (C-6“"6).

$[\alpha]_{\mathrm{D}}^{22}=-39.3^{\circ}(\mathrm{MeOH}, \mathrm{c}=0.54)$.

IR (ATR) $v\left(\mathrm{~cm}^{-1}\right)=3533-3050,2928,1620,1513$, 1433, 1173, 1076, 1023, 944.

HRMS (ESI) $m / z:[\mathrm{M}+\mathrm{Na}]^{+}$Calculated for $\mathrm{C}_{20} \mathrm{H}_{22} \mathrm{O}_{8} \mathrm{Na} 413.1212$; Found: 413.1213.

Compound 2: Ethanone, 1-[2- $(\beta-$ glucopyranosyloxy)-4-hydroxy-6-methylphenyl)].

${ }^{1} \mathrm{H}$ NMR (600 MHz, DMSO- $\left.d_{6}\right) \delta 6.42(\mathrm{~d}, J=2.0$

$\mathrm{Hz}, 1 \mathrm{H}, \mathrm{H}-3), 6.27$ (d, $J=2.0 \mathrm{~Hz}, 1 \mathrm{H}, \mathrm{H}-5), 5.29$ (d, $J$ $\left.=5.4 \mathrm{~Hz}, 1 \mathrm{H}, \mathrm{C}-2^{6}-\mathrm{OH}\right), 5.11\left(\mathrm{~s}, 1 \mathrm{H}, \mathrm{C}-3^{\circ}-\mathrm{OH}\right), 5.05(\mathrm{~s}$, $\left.1 \mathrm{H}, \mathrm{C}-4^{\circ}-\mathrm{OH}\right), 4.83$ (d, J=7.7 Hz, 1H, H-1 ' ), 4.56 (s, 1H, C-6'-OH), 3.68 (dd, $J=11.9,2.1 \mathrm{~Hz}, 1 \mathrm{H}, \mathrm{H}-6^{\circ}$ ), 3.48 (dd, $\left.J=11.9,5.4 \mathrm{~Hz}, 1 \mathrm{H}, \mathrm{H}-6^{\circ}\right), 3.31-3.23$ (m, 2H, H-3', H-5 $\left.{ }^{\circ}\right), 3.23-3.15$ (m, 2H, H-2 ${ }^{\circ}, \mathrm{H}-4^{\circ}$ ) , 2.43 (s, 3H, CO$M e), 2.08$ (s, 3H, C-6-Me ).

${ }^{13} \mathrm{C}$ NMR (151 MHz, DMSO) $\delta 203.4(\mathrm{C}=\mathrm{O}), 159.2$ (C-4), 156.4 (C-2), 137.1 (C-6), 122.5 (C-1), 111.0 (C5), 100.5 (C-1'), 99.9 (C-3), 77.1 (C-5'), 76.8 (C-3 $\left.{ }^{\circ}\right)$, $73.3\left(\mathrm{C}-2^{\circ}\right), 69.5\left(\mathrm{C}-4^{\circ}\right), 60.6\left(\mathrm{C}^{\circ} 6^{6}\right), 32.7$ (CO-Me), 19.6 (C-6-Me).

$[\alpha]_{\mathrm{D}}^{22}=-35.6^{\circ}(\mathrm{MeOH}, \mathrm{c}=0.46)$.

IR $(A T R) v\left(\mathrm{~cm}^{-1}\right)=3650-3000,2928,1654,1605$, 1464, 1328, 1258, 1173, 1077.

HRMS (ESI) $m / z:[\mathrm{M}+\mathrm{Na}]^{+}$Calculated for $\mathrm{C}_{15} \mathrm{H}_{20} \mathrm{O}_{8} \mathrm{Na}$ 351.1056; Found: 351.1047.

Compound 3: Lyoniside (major diastereomere being contaminated with a minor diastereomere).

${ }^{1} \mathrm{H}$ NMR (600 MHz, DMSO- $\left.d_{6}\right) \delta 8.18(\mathrm{~s}, 1 \mathrm{H})$, 8.02 (s, 1H), 6.54 (s, 0H), 6.53 (s, 1H, H-8), 6.32 (s, 2H, H-2 ', H-6') 6.28 (s, 1H), 5.20 (d, J=4.9 Hz, 1H, C-2“" $\mathrm{OH}), 5.06$ (d, $J=4.3 \mathrm{~Hz}, 1 \mathrm{H}, \mathrm{C}-4$ “" $-\mathrm{OH}), 5.04$ (s, 0H), $5.00(\mathrm{~d}, J=4.9 \mathrm{~Hz}, 1 \mathrm{H}, \mathrm{C}-3$ “'-OH), 4.48 (t, $J=5.1 \mathrm{~Hz}$, $\left.1 \mathrm{H}, \mathrm{CH}_{2}-\mathrm{OH}\right), 4.45$ (t, $\left.J=5.1 \mathrm{~Hz}, 0 \mathrm{H}\right), 4.25(\mathrm{~d}, J=6.6$ $\mathrm{Hz}, 1 \mathrm{H}, \mathrm{H}-4), 4.14$ (d, $J=6.2 \mathrm{~Hz}, 0 \mathrm{H}), 4.10$ (d, $J=7.7$ $\mathrm{Hz}, 1 \mathrm{H}, \mathrm{H}-1^{\mathrm{c}}$ ), 4.05 (d, $\left.J=7.6 \mathrm{~Hz}, 0 \mathrm{H}\right), 3.76$ (s, 1H), 3.76 (s, 3H, C-7-OMe), $3.73-3.64$ (m, 2H, H-5 “, H-3 $\alpha$ ), 3.63 (s, 6H, C-3'-OMe, C-5'-OMe), $3.52-3.44$ (m, 1H, $\mathrm{H}-2 \alpha), 3.35$ (m (water signal), $1 \mathrm{H}, \mathrm{H}-2 \alpha), 3.30-3.24$ (m, 
1H, H-3“"), $3.24-3.23$ (m, 1H, H-3 2 ), 3.22 (s, 3H, C-5$\mathrm{OMe}$ ), $3.13-3.08$ (m, 1H, H-4“"), $3.04-2.98$ (m, 2H, H-2“, H-5“), $2.65-2.57$ (m, 1H, H-1), $2.54-2.51$ (m, $1 \mathrm{H}, \mathrm{H}-1), 1.94-1.86$ (m, 1H, H-3), 1.50 (dt, $J=11.4$, $7.7 \mathrm{~Hz}, 1 \mathrm{H}, \mathrm{H}-2)$.
${ }^{13} \mathrm{C}$ NMR (151 MHz, DMSO) $\delta 147.50\left(\mathrm{C}-3^{\circ}, \mathrm{C}-5^{\circ}\right)$, 146.94, 146.90 (C-7), 146.52 (C-5), 146.40, 137.69, $137.63\left(\mathrm{C}-1^{\circ}\right), 137.27$ (C-6), 137.24, 133.33, 133.24 (C$\left.4^{\circ}\right), 128.45,128.34$ (C-8a), 124.94 (C-4a), 124.79, 106.65 (C-8), 105.86 (C-2‘, C-6“), 104.10 (C-1““), 103.79, 76.85<smiles>[R]c1cc(O)c2c(c1)C(=O)c1cc([R])cc(O)c1C2=O</smiles>

\begin{tabular}{ccc} 
Compound & $\mathbf{R}_{\mathbf{1}}$ & $\mathbf{R}_{\mathbf{2}}$ \\
\hline Emodin & $\mathrm{CH}_{3}$ & $\mathrm{OH}$
\end{tabular}

$\begin{array}{cll}\text { Aloe-emodin } & \mathrm{CH}_{2} \mathrm{OH} & \mathrm{H} \\ \text { Rhein } & \mathrm{COOH} & \mathrm{H}\end{array}$

Physcion $\quad \mathrm{CH}_{3} \quad \mathrm{OCH}_{3}$
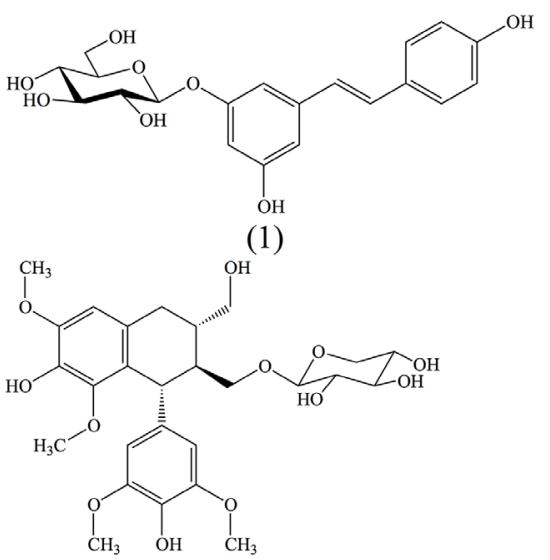

(3)

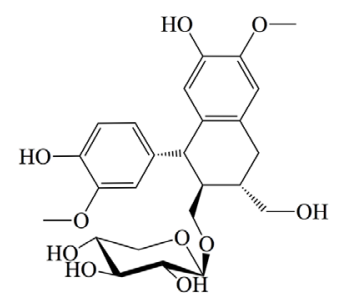

(5)<smiles>Oc1cc(O)c2c(c1)O[C@H](c1ccc(O)c(O)c1)[C@H](O)C2</smiles>

(7)<smiles>Cc1cc(O)c2c(c1)C(=O)c1cccc(OC(OCCO)C(O)C(O)CO)c1C2=O</smiles>

(10)<smiles>CC(=O)c1c(C)cc(O)cc1OC1OC(O)C(O)C(O)C1O</smiles>

(2)

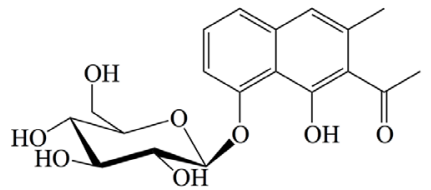

(4)

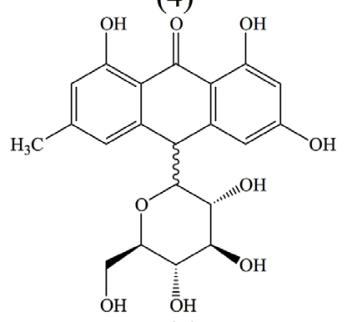

(6)

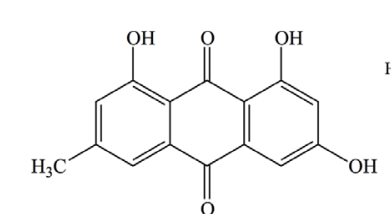

(8)

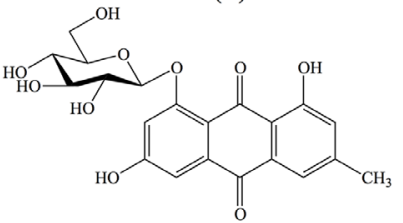

(9)<smiles>COc1cc(OC(O)[C@H](O)[C@H](O)CCO)c2c(c1)C(=O)c1cc(C)cc(O)c1C2=O</smiles>

(11)

Figure 1: Chemical structures of main anthraquinone aglycons and isolated compounds from $R$. acetosella $L$. 
(C-4“), 76.73, 73.31 (C-2“), 69.61 (C-3“), 68.86 (C-3a), 65.86, 65.78 (C-5”), 63.94, 63.65 (C-2 $\alpha), 58.79,58.62$ (C-5-OMe), 56.07 (C-3'-OMe, C-5'-OMe), 56.02, 55.67, 55.65 (C-7-OMe), 44.65 (C-3), 44.55, 41.03 (C-4), 40.95, 38.81 (C-2), 32.67 (C-1), 32.49.

$[\alpha]_{\mathrm{D}}^{22}=+3.6^{\circ}(\mathrm{MeOH}, \mathrm{c}=0.47)$.

IR (ATR) $v\left(\mathrm{~cm}^{-1}\right)=3550-3050,2934,2851,1611$, 1515, 1462, 1324, 1221, 1113, 1047, 1025, 994.

HRMS (ESI) $m / z:[\mathrm{M}+\mathrm{Na}]^{+}$Calculated for $\mathrm{C}_{27} \mathrm{H}_{36} \mathrm{O}_{12} \mathrm{Na}$ 575.2104; Found: 575.2093.

Compound 4: Musizin-/nepodin-8- $O-\beta$ glucopyranoside.

${ }^{1} \mathrm{H}$ NMR $\left(600 \mathrm{MHz}\right.$, Methanol- $\left.d_{4}\right) \delta 7.40(\mathrm{dd}, J=$ 8.1, 1.2 Hz, 1H, H-5), 7.35 (t, $J=7.9 \mathrm{~Hz}, 1 \mathrm{H}, \mathrm{H}-6), 7.31$ (dd, $J=7.7,1.2 \mathrm{~Hz}, 1 \mathrm{H}, \mathrm{H}-7), 7.13$ (d, $J=1.1 \mathrm{~Hz}, 1 \mathrm{H}$, H-4), 5.10 (d, $J=7.9 \mathrm{~Hz}, 1 \mathrm{H}, \mathrm{H}-1^{\circ}$ ), 3.93 (dd, $J=12.1,2.3$ $\left.\mathrm{Hz}, 1 \mathrm{H}, \mathrm{H}-6^{\circ}\right), 3.72$ (dd, $\left.J=12.1,5.9 \mathrm{~Hz}, 1 \mathrm{H}, \mathrm{H}-6^{\circ}\right), 3.54$ (dd, $\left.J=9.2,7.9 \mathrm{~Hz}, 1 \mathrm{H}, \mathrm{H}-2^{\prime}\right), 3.52-3.49$ (m, $1 \mathrm{H}, \mathrm{H}-5^{\circ}$ ), $3.47\left(\mathrm{t}, J=9.0 \mathrm{~Hz}, 1 \mathrm{H}, \mathrm{H}-3^{\circ}\right), 3.40(\mathrm{dd}, J=9.7,8.8 \mathrm{~Hz}$, $\left.1 \mathrm{H}, \mathrm{H}-4^{\circ}\right), 2.28$ (d, $\left.J=0.9 \mathrm{~Hz}, 3 \mathrm{H}, \mathrm{C}-3-M e\right)$.

${ }^{13} \mathrm{C}$ NMR (151 MHz, MeOD) $\delta 208.37(C=\mathrm{O})$, 156.18 (C-8), 152.93 (C-1), 138.11 (C-4a), 134.67 (C-3), 128.58 (C-6), 126.09 (C-2), 123.87 (C-5), 120.93 (C-4), 114.95 (C-8a), 111.86 (C-7), 104.34 (C-1'), 78.86 (C-5'), 78.17 (C-3'), 74.99 (C-2'), 71.29 (C-4'), 62.48 (C-6'), $31.81(\mathrm{CO}-\mathrm{Me}), 19.91(\mathrm{C}-3-\mathrm{Me})$.

$[\alpha]_{\mathrm{D}}^{22}=-53.5^{\circ}(\mathrm{EtOH}, \mathrm{c}=0.26)$.

IR $($ ATR $) v\left(\mathrm{~cm}^{-1}\right)=3385,3298,2964,2925,1670$, $1578,1354,1079$.

HRMS (ESI) $m / z:[\mathrm{M}+\mathrm{Na}]^{+}$Calculated for $\mathrm{C}_{19} \mathrm{H}_{22} \mathrm{O}_{8} \mathrm{Na} 401.1212$; Found: 401.1201.

Compound 5: $\quad(+)$-Isolariciresinol-9- $O-\beta-$ xylopyranoside.

${ }^{1} \mathrm{H}$ NMR (600 MHz, DMSO- $d_{6}$ ) $\delta 8.74$ (s, 1H, C-4'$\mathrm{OH}), 8.44$ (s, 1H, C-7-OH), 6.79 (d, J=2.0 Hz, 1H, H-2'), $6.68(\mathrm{~d}, J=8.0 \mathrm{~Hz}, 1 \mathrm{H}, \mathrm{H}-5$ ') 6.59 (s, 1H, H-5), 6.47 (dd, $J=8.1,1.9 \mathrm{~Hz}, 1 \mathrm{H}, \mathrm{H}-6$ '), 6.06 (s, 1H, H-8), 5.24 (d, $J$ $=4.7 \mathrm{~Hz}, 1 \mathrm{H}, \mathrm{C}-2$ "'-OH), $4.99(\mathrm{~d}, J=4.8 \mathrm{~Hz}, 1 \mathrm{H}, \mathrm{C}-3$ " $\mathrm{OH}), 4.95$ (d, $J=5.0 \mathrm{~Hz}, 1 \mathrm{H}, \mathrm{C}-4$ "'-OH), 4.41 (t, $J=5.1$ $\mathrm{Hz}, 1 \mathrm{H}, \mathrm{C}-3 \alpha-\mathrm{OH}), 4.02$ (d, $J=10.9 \mathrm{~Hz}, 1 \mathrm{H}, \mathrm{H}-1), 3.90$ (d, $J=7.6 \mathrm{~Hz}, 1 \mathrm{H}, \mathrm{H}-1$ '), 3.84 (dd, $J=9.6,2.4 \mathrm{~Hz}, 1 \mathrm{H}$, $\mathrm{H}-2 \alpha$ ), 3.71 (s, 3H, C-3'-OMe), 3.70 (s, 3H, C-6-OMe), 3.64 (dd, $J=11.3,5.4 \mathrm{~Hz}, 1 \mathrm{H}, \mathrm{H}-5$ "), 3.57 (dt, $J=10.5$, $4.2 \mathrm{~Hz}, 1 \mathrm{H}, \mathrm{H}-3 \alpha), 3.46(\mathrm{dt}, J=11.0,5.9 \mathrm{~Hz}, 1 \mathrm{H}, \mathrm{H}-3 \alpha$ ), 3.26 (ddt, $J=10.4,8.8,5.2 \mathrm{~Hz}, 1 \mathrm{H}, \mathrm{H}-4$ "), 3.07 (td, $J=$ 8.8, $4.8 \mathrm{~Hz}, 1 \mathrm{H}, \mathrm{H}-3$ "), 3.00 - 2.94 (m, 3H, H-2 $\alpha, \mathrm{H}-2$ ", H-5"), $2.73-2.70$ (m, 2H, H-4), 1.86 (ddq, $J=13.1,6.2$, $3.5 \mathrm{~Hz}, 1 \mathrm{H}, \mathrm{H}-3$ ), 1.68 (tt, $J=10.7,2.7 \mathrm{~Hz}, 1 \mathrm{H}, \mathrm{H}-2$ ).

${ }^{13} \mathrm{C}$ NMR (151 MHz, DMSO) $\delta 147.14$ (C-3'), 145.50 (C-6), 144.47 (C-4'), 144.03 (C-7), 136.91 (C-1'), 132.62 (C-9/8a), 127.02 (C-10/4a), 121.05 (C-6'), 116.27 (C-8), 115.48 (C-5'), 113.86 (C-2'), 111.76 (C-5), 104.59 (C-1"), 76.59 (C-3"), 73.37 (C-2”), 69.58 (C-4”), 67.23

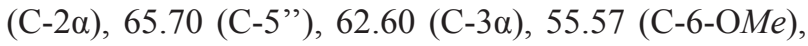
55.48 (C-3'-OMe), 45.64 (C-1), 44.11 (C-2), 37.56 (C-3), $32.63(\mathrm{C}-4)$.
$[\alpha]_{\mathrm{D}}^{22}=+16.9^{\circ}(\mathrm{MeOH}, \mathrm{c}=0.19)$.

HRMS (ESI) $m / z:[\mathrm{M}+\mathrm{Na}]^{+}$Calculated for $\mathrm{C}_{25} \mathrm{H}_{32} \mathrm{O}_{10} \mathrm{Na}$ 515.1893; Found: 515.1904.

Compound 6: Rumejaposide G/H diastereomeric mixture.

${ }^{1} \mathrm{H}$ NMR (600 MHz, DMSO- $\left.d_{6}\right) \delta 12.17(\mathrm{~s}, 1 \mathrm{H}$, C-1-OH, A), 12.16 (s, 1H, C-1-OH-B), 12.00 (s, 1H, C-8OH, A), 12.00 (s, 1H, C-8-OH, B), 10.74 (s, 2H, C-3-OH, both), 6.88 (d, $J=1.4 \mathrm{~Hz}, 1 \mathrm{H}, \mathrm{H}-5, \mathrm{~A}), 6.84(\mathrm{~s}, 1 \mathrm{H}, \mathrm{H}-5$, B), 6.68 (s, 1H, H-7, A), 6.67 (s, 1H, H-7, B), 6.52 (d, $J=$ $2.2 \mathrm{~Hz}, 1 \mathrm{H}, \mathrm{H}-4, \mathrm{~B}), 6.47$ (d, $J=2.3 \mathrm{~Hz}, 1 \mathrm{H}, \mathrm{H}-4, \mathrm{~A}), 6.22$ (d, $J=2.3 \mathrm{~Hz}, 1 \mathrm{H}, \mathrm{H}-2$. A), 6.20 (d, $J=2.2 \mathrm{~Hz}, 1 \mathrm{H}, \mathrm{H}-2$, B), 5.19 (d, $J=5.9 \mathrm{~Hz}, 1 \mathrm{H}, \mathrm{C}-2$ '-OH, A), 5.14 (d, $J=5.9$ $\mathrm{Hz}, 1 \mathrm{H}, \mathrm{C}-2$ '-OH, B), 4.94 (d, $J=5.0 \mathrm{~Hz}, 1 \mathrm{H}, \mathrm{C}-3$ '-OH, B), 4.92 (d, $J=4.9 \mathrm{~Hz}, 1 \mathrm{H}, \mathrm{C}-3$ '- $\mathrm{OH}, \mathrm{A}), 4.79-4.76$ (m, 2H, C-4'-OH, both), 4.42 (d, $J=2.1 \mathrm{~Hz}, 1 \mathrm{H}, \mathrm{H}-10, \mathrm{~B}$ ), 4.41 (d, $J=2.1 \mathrm{~Hz}, 1 \mathrm{H}, \mathrm{H}-10, \mathrm{~A}), 3.89$ (pseudo-q, $J=5.5$ Hz, 2H, C-6'-OH, both), $3.42-3.36$ (m, 1H, H-6', both), 3.27 (dd, $\left.J=9.2,2.2 \mathrm{~Hz}, 1 \mathrm{H}, \mathrm{H}-1^{\prime}, \mathrm{A}\right), 3.26$ (dd, $J=9.2$, $\left.2.2 \mathrm{~Hz}, 1 \mathrm{H}, \mathrm{H}-1^{\prime}, \mathrm{B}\right), 3.19-3.13$ (m, 2H, H-6', both), $3.13-3.06$ (m, 2H, H-3', both), 2.92 (td, $J=9.2,5.9 \mathrm{~Hz}$, 1H, H-2', B), 2.84 (td, $J=9.2,5.9 \mathrm{~Hz}, 1 \mathrm{H}, \mathrm{H}-2^{\prime}$, A), 2.79 (ddd, $J=9.8,5.8,2.2 \mathrm{~Hz}, 1 \mathrm{H}, \mathrm{H}-5$ ', A), $2.74-2.68$ (m, $3 \mathrm{H}, \mathrm{H}-4$ ' both, H-5' B), 2.34 (s, 3H, C-6-Me, A), 2.33 (s, $3 \mathrm{H}, \mathrm{C}-6-\mathrm{Me}, \mathrm{B})$.

${ }^{13} \mathrm{C}$ NMR (151 MHz, DMSO) $\delta 191.86(\mathrm{C}=\mathrm{O}$, both), 164.84 (C-3, A), 164.32 (C-3, B), 164.15 (C-1, A), 164.07 (C-1, B), 161.32 (C-8, A), 161.12 (C-8, B), 148.51 (C-5a, A), 146.89 (C-6, B), 146.11 (C-6, A), 145.84 (C-5a, B), 144.61 (C-4a, B), 142.06 (C-4a, A), 121.58 (C-5, A), 120.15 (C-5, B), 116.20 (C-7, A), 115.97 (C-7, B), 115.18 (C-8a, A), 115.06 (C-8a, B), 110.74 (C-9a, B), 110.54 (C-9a, A), 109.71 (C-4, B), 107.96 (C-4, A), 101.64 (C-2, A), 101.55 (C-2, B), 86.33 (C-1', A), 86.15 (C-1', B), 81.38 (C-5', B), 81.28 (C-5', A), 78.68 (C-3', B), 78.64 (C-3', A), 70.74 (C4', B), 70.71 (C-4', A), 70.53 (C-2', A), 70.31 (C-2', B), 61.87 (C-6', B), 61.78 (C-6', A), 44.44 (C-10, A), 44.16 (C-10, B), 22.12 (C-6-Me, A), 22.10 (C-6-Me, B).

$[\alpha]_{\mathrm{D}}^{22}=-3.2^{\circ}(\mathrm{MeOH}, \mathrm{c}=0.22)$.

IR (ATR) $v\left(\mathrm{~cm}^{-1}\right)=3550-3050,1620,1481,1368$, 1284, 1150, 1025, 992.

HRMS (ESI) $m / z:[\mathrm{M}+\mathrm{Na}]^{+}$Calculated for $\mathrm{C}_{21} \mathrm{H}_{22} \mathrm{O}_{9} \mathrm{Na}$ 441.1162; Found: 441.1169 .

Compound 7: (-)-Catechin/flavan-3-ol.

${ }^{1} \mathrm{H}$ NMR (600 MHz, DMSO- $\left.d_{6}\right) \delta 9.14(\mathrm{~s}, 1 \mathrm{H}, \mathrm{Ar}-$ $\mathrm{OH}), 8.92$ (s, 2H, 2x Ar-OH), 8.85 (s, 1H, Ar-OH), 6.88 (d, $\left.J=1.9 \mathrm{~Hz}, 1 \mathrm{H}, \mathrm{H}-2^{\circ}\right), 6.66\left(\mathrm{~d}, J=8.1 \mathrm{~Hz}, 1 \mathrm{H}, \mathrm{H}-5^{\circ}\right.$ ), $6.63\left(\mathrm{dd}, J=8.1,1.9 \mathrm{~Hz}, 1 \mathrm{H}, \mathrm{H}-6^{\circ}\right), 5.89(\mathrm{~d}, J=2.3 \mathrm{~Hz}$, $1 \mathrm{H}, \mathrm{H}-6), 5.71$ (d, $J=2.3 \mathrm{~Hz}, 1 \mathrm{H}, \mathrm{H}-8), 4.72$ (s, $1 \mathrm{H}, \mathrm{H}-2)$, 4.68 (s, 1H, C-3-OH), 3.99 (s, 1H, H-3), 2.67 (dd, $J=$ 16.3, $4.5 \mathrm{~Hz}, 1 \mathrm{H}, \mathrm{H}-4), 2.49-2.45$ (m, 1H, H-4).

${ }^{13} \mathrm{C}$ NMR (151 MHz, DMSO) $\delta 156.56$ (C-7), 156.25 (C-5), 155.79 (C-8a), 144.55 (C-4'), 144.52 (C3'), 130.58 (C-1'), 117.93 (C-6'), 114.90 (C-2'), 114.76 (C-5'), 98.47 (C-4a), 95.05 (C-6), 94.06 (C-8), 78.08 (C2), 64.93 (C-3), 28.26 (C-4). 
$[\alpha]_{\mathrm{D}}^{22}=-12.6^{\circ}(\mathrm{MeOH}, \mathrm{c}=0.32)$.

IR $($ ATR $) v\left(\mathrm{~cm}^{-1}\right)=3571-3050,2965,1626,1605$, 1468, 1284, 1147, 1024, 911.

MS (ESI) $m / z:[\mathrm{M}+\mathrm{H}]^{+} 291.1$.

Compound 8: Emodin.

${ }^{1} \mathrm{H}$ NMR (600 MHz, DMSO- $\left.d_{6}\right) \delta 13.15(\mathrm{~s}, 1 \mathrm{H}$, $\mathrm{OH}), 12.41(\mathrm{~s}, 1 \mathrm{H}, \mathrm{OH}), 7.36(\mathrm{~s}, 1 \mathrm{H}, \mathrm{H}-4), 7.00(\mathrm{~s}, 1 \mathrm{H}$, H-2), 6.52 (d, $J=2.3 \mathrm{~Hz}, 1 \mathrm{H}, \mathrm{H}-5), 5.62$ (d, $J=2.3 \mathrm{~Hz}$, $1 \mathrm{H}, \mathrm{H}-7), 2.35$ (s, 3H, C-6-Me).

${ }^{13} \mathrm{C}$ NMR (151 MHz, DMSO) $\delta 184.48$ (C-10), 181.52 (C-9), 166.55, 166.44 (C-6/C-8), 161.22 (C-1), 144.93 (C3), 134.35 (C-11), 133.37 (C-14), 123.90 (C-2), 119.40 (C-4/C-5), 115.34 (C-13), 101.64 (C-12), 107.92 (C-7), 21.76 (C-3-Me).

IR $($ ATR $) v\left(\mathrm{~cm}^{-1}\right)=1683,1653,1478,1273,758$

MS (ESI) $m / z:[\mathrm{M}+\mathrm{H}]^{+} 271.2$.

Compound 9: Emodin-8- $O$ - $\beta$-glucopyranoside.

${ }^{1} \mathrm{H}$ NMR (600 MHz, DMSO- $\left.d_{6}\right) \delta 7.31$ (d, $J=1.6$ $\mathrm{Hz}, 1 \mathrm{H}, \mathrm{H}-4), 6.98$ (d, $J=1.6 \mathrm{~Hz}, 1 \mathrm{H}, \mathrm{H}-2), 6.59$ (d, $J=$ $2.4 \mathrm{~Hz}, 1 \mathrm{H}, \mathrm{H}-5), 6.20$ (d, $J=2.4 \mathrm{~Hz}, 1 \mathrm{H}, \mathrm{H}-7), 4.66$ (d, $J$ $=7.1 \mathrm{~Hz}, 1 \mathrm{H}, \mathrm{H}-1^{\prime}$ ), 3.73 (d, $J=12.1 \mathrm{~Hz}, 1 \mathrm{H}, \mathrm{H}-6$ 'a), 3.50 (d, $J=1.6 \mathrm{~Hz}, 1 \mathrm{H}, \mathrm{H}-6$ 'b), $3.34-3.25$ (m, $\mathrm{H}_{2} \mathrm{O}$ signal, H-2', H-3', H-5'), 3.19 (t, $J=8.8$ Hz, 1H, H-4'), 2.34 (s, $3 \mathrm{H}, \mathrm{C}-3-\mathrm{Me})$.

${ }^{13} \mathrm{C}$ NMR (151 MHz, DMSO) $\delta 184.73$ (C-10), 180.12 (C-9), 163.94 (C-6 and C-8), 161.76 (C-1), 144.14 (C-3), 135.62 (C-5a), 132.49 (C-4a), 123.69 (C-2), 118.23 (C-5), 118.07 (C-4), 115.76 (C-1a), 111.97 (C-7), 103.69 (C-1'), 103.53 (C-8a), 77.58 (C-5'), 75.62 (C-2'), 73.57 (C-3’), 69.79 (C-4'), 60.79 (C-6'), 21.36 (C-3-Me).

${ }^{1} \mathrm{H}$ NMR (600 MHz, Methanol- $\left.d_{4}\right) \delta 7.47(\mathrm{~d}, J=1.7$ $\mathrm{Hz}, 1 \mathrm{H}, \mathrm{H}-4), 7.14$ (d, $J=2.5 \mathrm{~Hz}, 1 \mathrm{H}, \mathrm{H}-5), 7.02-7.00$ (m, 1H, H-2), 6.78 (d, $J=2.5 \mathrm{~Hz}, 1 \mathrm{H}, \mathrm{H}-7), 3.94$ (dd, $J=$ 12.2, 1.6 Hz, 1H, H-6'a), 3.80 (dd, $J=12.2,4.2 \mathrm{~Hz}, 1 \mathrm{H}$, H-6'b), $3.63-3.59$ (m, 1H, H-2'), $3.55-3.45$ (m, 3H, H-3', H-4', H-5'), 2.39 (s, 3H, C-3-Me).

${ }^{13} \mathrm{C}$ NMR (151 MHz, MeOD) $\delta 185.38$ (C-10), 178.72 (C-9), 164.32 (C-6 and C-8), 163.48 (C-1), 147.36 (C-3), 137.83 (C-10a), 134.37 (C-4a), 125.00 (C-2), 120.31 (C-4), 116.77 (C-5), 116.59 (C-9a), 113.94 (C-7), 110.08 (C-8a), 104.80 (C-1'), 78.60 (C-5'), 77.28 (C-3'), 74.81 (C-2'), 71.02 (C-4'), 62.29 (C-6'), 21.82 (C-3-Me).

$[\alpha]_{\mathrm{D}}^{22}=$ not possible due to high absorption.

IR $(A T R) \vee\left(\mathrm{cm}^{-1}\right)=3550-3050,1629,1480,1366$, 1266, 1074, 1025, 991 .

Compounds 10 and 11: Mixture of chrysophanol8 - $O$ - $\beta$-glucopyranoside and physcion-8- $O-\beta$ glucopyranoside.

${ }^{1} \mathrm{H}$ NMR (600 MHz, DMSO- $\left.d_{6}\right) \delta 7.85(\mathrm{~d}, J=8.0 \mathrm{~Hz}$, 1H, H-5, A), 7.81 (t, $J=8.0 \mathrm{~Hz}, 1 \mathrm{H}, \mathrm{H}-6, \mathrm{~A}), 7.67$ (d, $J=8.0$ Hz, 1H, H-7, A), 7.35 (d, J=2.5 Hz, 1H, H-5, B), 7.17 (d, $J=2.5 \mathrm{~Hz}, 1 \mathrm{H}, \mathrm{H}-7, \mathrm{~B}), 7.44 / 7.38 / 7.15 / 7.11$ (broad signals which might be $\mathrm{H}-5$ and $\mathrm{H}-7), 5.16$ (d, $J=7.7 \mathrm{~Hz}, 1 \mathrm{H}, \mathrm{H}-1$ ', B), 5.12 (d, J=7.7 Hz, 1H, H-1', A), 3.95 (s, 3H, C-6-OMe, B), $3.73-3.68$ (m, 2H, H-6', H-6', A and B), 3.50 (t, $J=6.0$ Hz, 2H, H-6', H-6', A and B), $3.49-3.31$ (m, 6H, water,
H-2', H-2', H-3', H-3', H-5', H-5', A and B), 3.22 (t, $J=9.3$ Hz, 1H, H-4', A), 3.18 (t, J=9.0 Hz, 1H, H-4', B), 2.40 (s, 3H, C-3-Me, B), 2.38 (s, 3H, C-3-Me, A).

${ }^{13} \mathrm{C}$ NMR (151 MHz, DMSO) $\delta 182.54$ (C-10, A), 182.14 (C-10, B), 164.54 (C-6, B), 160.65 (C-8, B), 158.09 (C-8, A), 146.83 (C-3, A) 136.35 (C-14, B), 135.37 (C-6, A), 134.79 (C-14, A), 124.82 (C-2, B), 122.42 (C7, A), 121.62 (C-13, A), 120.35 (C-5, A), 118.82 (C-4, B), 118.17 (C-4, A?), 114.68 (C-13, B), 107.30 (C-7, B), 106.31 (C-5, B), 100.68 (C-1', B), 100.64 (C-1', A), 77.51 (C-5', B), 77.34 (C-5', A), 76.60 (C-3', B), 76.45 (C-3', A), 73.24 (C-2', C-2', A and B), 69.79 (C-4', B), 69.54 (C4', A), 60.76 (C-6', B), 60.60 (C-6', A), 56.09 (C-6-OMe, B), 21.48 (C-3-Me, A), 21.44 (C-3-Me, B).

$[\alpha]_{\mathrm{D}}^{22}=-21.8^{\circ}(\mathrm{MeOH}, \mathrm{c}=0.17)$.

MS (ESI) $m / z:[\mathrm{M}+\mathrm{Na}]^{+} 439.1$ and 469.1 .

\section{Cytotoxicity of anthraquinones towards sensitive and drug-resistant cancer cells}

As a first step, the cytotoxicity of the main anthraquinones in $R$. acetosella was investigated towards drug-sensitive CCRF-CEM and multidrug-resistant P-glycoprotein-overexpressing CEM/ADR5000 leukemia cells by means of the resazurin assay.

The $\mathrm{IC}_{50}$ values of emodin, Aloe-emodin, rhein and physcion were $35.62 \mu \mathrm{M}, 9.872 \mu \mathrm{M}, 34.42 \mu \mathrm{M}$ and $123.5 \mu \mathrm{M}$, respectively, for CCRF-CEM cells and 35.27, $12.85,46.87$ and $74.79 \mu \mathrm{M}$, respectively, for CEM/ ADR5000 cells (Figure 2). The degrees of resistance were calculated by dividing the $\mathrm{IC}_{50}$ values of CEM/ADR5000 cells by the $\mathrm{IC}_{50}$ values of CCRF-CEM. Collateral sensitivity (hypersensitivity) of CEM/ADR5000 cells was observed towards physcion (0.61-fold) compared to their corresponding sensitive cells. Aloe-emodin was the most cytotoxic compound among the four anthraquinones with $\mathrm{IC}_{50}$ values of $9.872 \mu \mathrm{M}$ (CCRF-CEM) and 12.85 $\mu \mathrm{M}$ (CEM/ADR5000) (Figure 2). Cytotoxic effects were not measured for compounds 3 and 5, since the isolated amounts were too small to perform for dose response experiments. Doxorubicin as clinically established anticancer drug served as control. The $\mathrm{IC}_{50}$ values for doxorubicin were $0.0007 \mu$ Mand $10.98 \mu \mathrm{M}$ towards CCRFCEM and CEM/ADR5000, respectively (Figure 3A). It is worth noting that the $\mathrm{IC}_{50}$ value of CEM/ADR5000 cells for Aloe-emodin was similar to that of doxorubicin. As Aloeemodin exerted the most profound cytotoxicity in sensitive and multidrug-resistant leukemia cell lines, we conducted further experiments solely with Aloe-emodin.

As a next step, we tested the cytotoxicity of Aloeemodin towards paired cell lines of different tumor types and drug resistance mechanisms. The following cell lines were treated with Aloe-emodin and measured by the resazurin assay:

(1) Breast cancer cells: MDA-MB-231-pcDNA cells and a multidrug-resistant subline transfected with a $B C R P$ cDNA (MDA-MB-231-BCRP clone 23). 
(2) Embryonic kidney cells: wild type HEK293 cells and a multidrug-resistant subline transfected with an $A B C B 5$ cDNA (HEK293-ABCB5).

(3) Colon cancer cells: HCT116 cells with wildtype TP53 tumor supressor gene (HCT116 $\left.\left(\mathrm{p} 53^{+/+}\right)\right)$and HCT116 knockout cells (HCT116 (p53-/)).

(A)

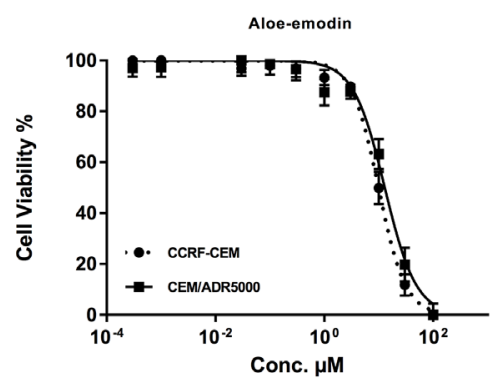

(C)

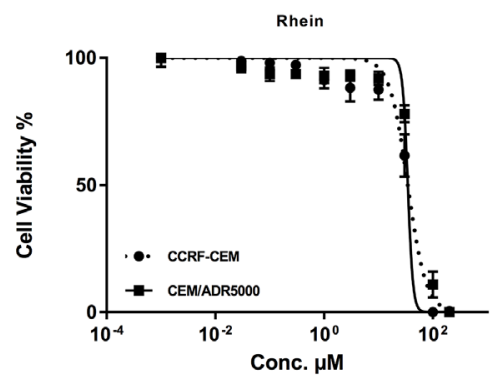

(E)

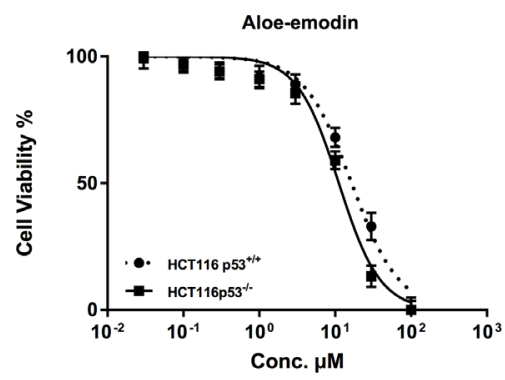

(G)

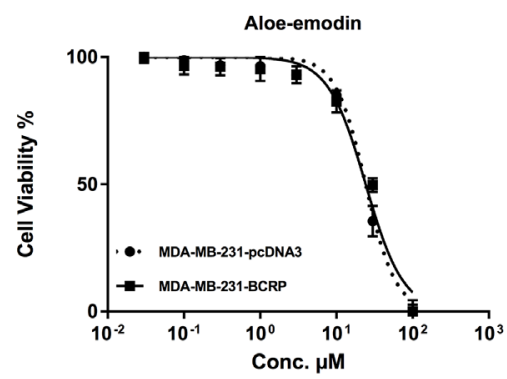

(4) Brain tumor cells: wild type U87.MG and a subline transfected with a deletion-activated $E G F R$ cDNA (U87.MG $\triangle \mathrm{EGFR}$ ).

As shown in Figure 2, the $\mathrm{IC}_{50}$ values ranged from $16.47 \mu \mathrm{M}$ to $22.3 \mu \mathrm{M}$ for drug-sensitive wild-type cell lines and from $11.19 \mu \mathrm{M}$ to $33.76 \mu \mathrm{M}$ for drug-resistant

(B)

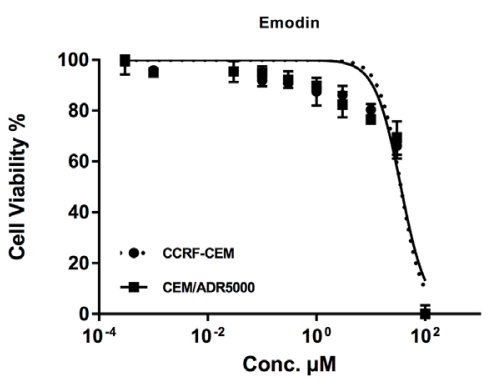

(D)

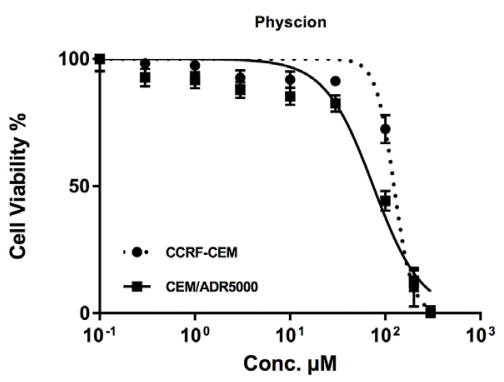

(F)

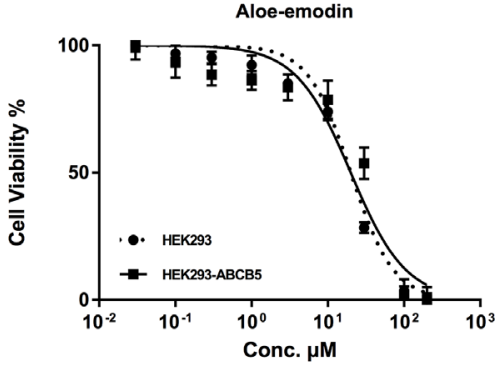

(H)

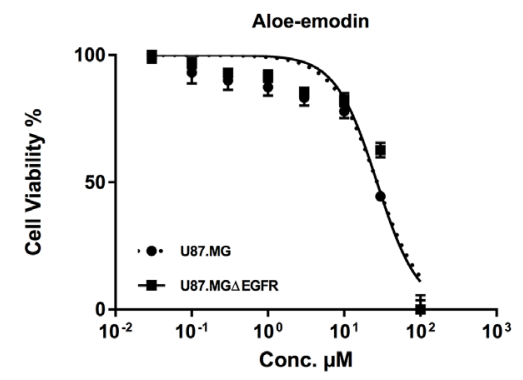

Figure 2: Cytotoxicity of Aloe-emodin (A), emodin (B), rhein (C) and physcion (D) towards sensitive CCRF-CEM and multidrug-resistant P-glycoprotein-expressing CEM/ADR5000 acute lymphoblastic cells and of Aloe-emodin as the most cytotoxic compound towards HCT116 $\left(p 53^{+/+}\right)$colon cancer cells and its knockout clone HCT116 ( $\left.p 53^{-/}\right)(\mathbf{E})$, HEK293 human embryonic kidney cells and its resistant counterpart HEK293/ ABCB5 transfected with a cDNA of $A B C B 5$ (F), MDA-MB-231-pcDNA3 breast cancer cells and its resistant subline MDA-MB-231BCRP clone 23 (G), and U87. MG glioblastoma cells and its transfected subline U87.MG $\triangle E G F R$, respectively (H). Mean values \pm SD of three independent experiments are shown. 
and/or transfected sublines. The $\mathrm{IC}_{50}$ values of aloeemodin towards HCT116(p53 $\left.{ }^{+/+}\right)$, U87.MG, MDA-MB231-pcDNA and HEK293 were $16.47 \mu \mathrm{M}, 21.73 \mu \mathrm{M}, 22.3$ $\mu \mathrm{M}$ and $16.9 \mu \mathrm{M}$, respectively. For resistant cell lines the $\mathrm{IC}_{50}$ values were detected as $11.19 \mu \mathrm{M}\left(\mathrm{HCT} 116\left(\mathrm{p} 53^{-/-}\right)\right)$, $33.76 \mu \mathrm{M}$ (U87.MG $\triangle \mathrm{EGFR}$ ), $26.95 \mu \mathrm{M}$ (MDA-MB231-BCRP clone 23) and $25.92 \mu \mathrm{M}$ (HEK293-ABCB5), respectively. Collateral sensitivity (hypersensitivity) to Aloe-emodin was observed in HCT116 (p53 $\left.{ }^{-/}\right)$knockout cells (0.68-fold).

\section{Cytotoxicity of Aloe-emodin towards CCRF- CEM cells by means of protease viability marker assay}

The cytotoxicity of Aloe-emodin was further investigated by means of a protease viability marker assay, in order to rule out any reciprocal interdependence of ROS with the resazurin assay. Since Aloe-emodin induced excessive ROS generation, an interaction with the results of resazurin assay might be suspected. Therefore, we performed a protease viability marker assay, measuring the protease activity within living cells. Aloe-emodin presented strong cytotoxicity towards CCRF-CEM cells with the $\mathrm{IC}_{50}$ value of $13.8 \mu \mathrm{M}$, which was quite similar to the data gained by the resazurin assay (Figure 3B).

\section{Toxicity of Aloe-emodin in normal cells}

We also investigated Aloe-emodin's toxicity towards normal cells. Human peripheral mononuclear cells (PMNC) were isolated from fresh blood samples of a healthy donor and tested against various concentrations of Aloe-emodin ranging from 0.001-100 $\mu \mathrm{M}$.

Interestingly, Aloe-emodin did not show cytotoxic activity towards the normal cells at all concentrations tested (varying from 0.001-100 $\mu \mathrm{M}$ ) (Figure 3C). On the contrary, the $\mathrm{IC}_{50}$ concentrations needed to kill sensitive and resistance leukemia cell lines as shown in Figure 2 were 9.872 and $12.85 \mu \mathrm{M}$, respectively, indicating that the inhibiting effect of aloe-emodin may be tumor-specific.

\section{Differential transcriptome-wide mRNA expression upon Aloe-emodin treatment}

We performed microarray hybridizations to find clues on the possible mechanisms of action of Aloeemodin. CCRF-CEM cells were treated with the $\mathrm{IC}_{50}$ of Aloe-emodin or DMSO for $48 \mathrm{~h}$. Using Chipster software, 1712 genes were deregulated upon Aloe-emodin treatment in comparison with DMSO treatment as control. These genes were subsequently subjected to Ingenuity Pathway Analysis (IPA) to obtain profiles of possibly affected signaling pathways. The most pronounced molecular and cellular functions identified by IPA were: cell death and survival, cellular growth and proliferation, cellular development, gene expression, cellular function and maintenance (Figure 4A).

\section{Validation of microarray data by qPCR}

The most deregulated genes of microarray analyses are shown in Figure 4B. Each two up- or down-regulated genes were selected for qPCR analysis (DUSP6, HHEX, $M C M D C 2, C R C P)$. Their expression was normalized to $G A P D H$. This gene was selected using the Bestkeeper technique (see Materials and Methods). Then, the foldchange values of Aloe-emodin-treated and untreated samples obtained from microarray hybridization and qPCR were subjected to Pearson correlation test. We obtained a correlation coefficient R-value of 0.989 , indicated a high consistency of microarray and qPCR data (Table 1).

\section{Detection of reactive oxygen species (ROS)}

IPA revealed that the deregulated genes were substantially correlated with apoptosis and other cellular functions including, DNA replication, recombination and repair. Therefore, we assumed that oxidative stress generated by Aloe-emodin may be a reason for DNA damage and ultimately apoptosis.

CCRF-CEM cells were treated with 0.5-, 1-, 2- or 4-fold $\mathrm{IC}_{50}$ of Aloe-emodin for $1 \mathrm{~h}$. As expected, Aloeemodin stimulated ROS production in a dose-dependent manner with fold changes $\geq 1.5$. Remarkably, Aloe-emodin induced even higher ROS generation than doxorubicin (1 $\mu \mathrm{M})$ or $\mathrm{H}_{2} \mathrm{O}_{2}(250 \mu \mathrm{M})$ as positive controls (Figure 5).

Excessive ROS production is known to evoke DNA damage in cells $[27,28]$. Pathway analysis of microarray results also showed that genes associated with DNA metabolism, replication, recombination and repair were deregulated (Figure 4A). This may imply that Aloe-emodin induces DNA damage. For this reason, we performed alkaline comet assay to detect single and double-stranded DNA damage.

\section{Comet assay}

Pathway analysis showed that DNA metabolism comprising DNA replication, recombination and repair was deregulated. Therefore, we tested Aloe-emodin's effect on the DNA by treating CCRF-CEM cells with 1-, 2or 4-fold $\mathrm{IC}_{50}$ of Aloe-emodinfor $24 \mathrm{~h}$. DMSO-treated cells served as negative control. Aloe-emodin indeed induced comet tails and increased percentages of tail DNA. We additionally monitored DNA migration with tail and olive tail movements and concluded that Aloe-emodin induced DNA damage in a dose-dependent manner (Figure 6).

\section{Cell cycle analysis}

Pathway analyses of microarray data indicated that genes associated with cell cycle progression were 
(A)

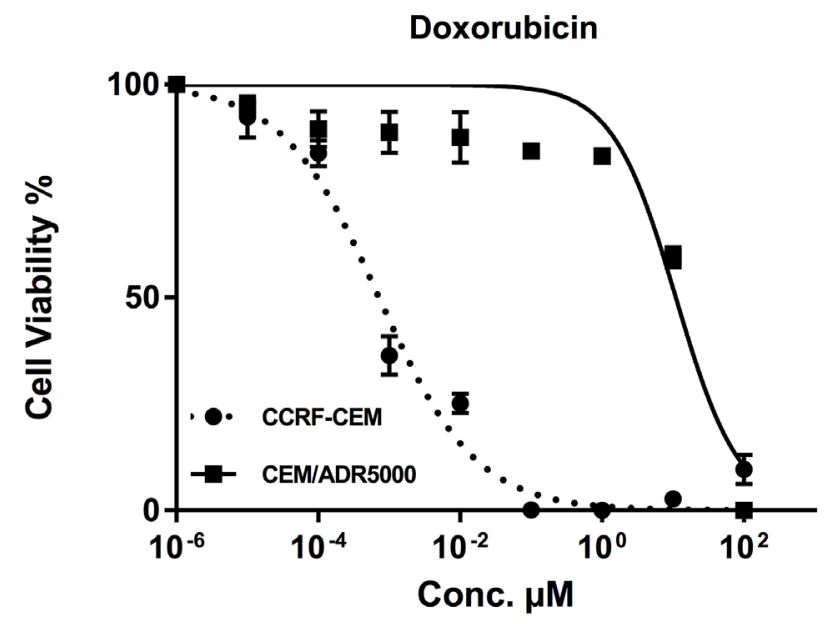

(B)

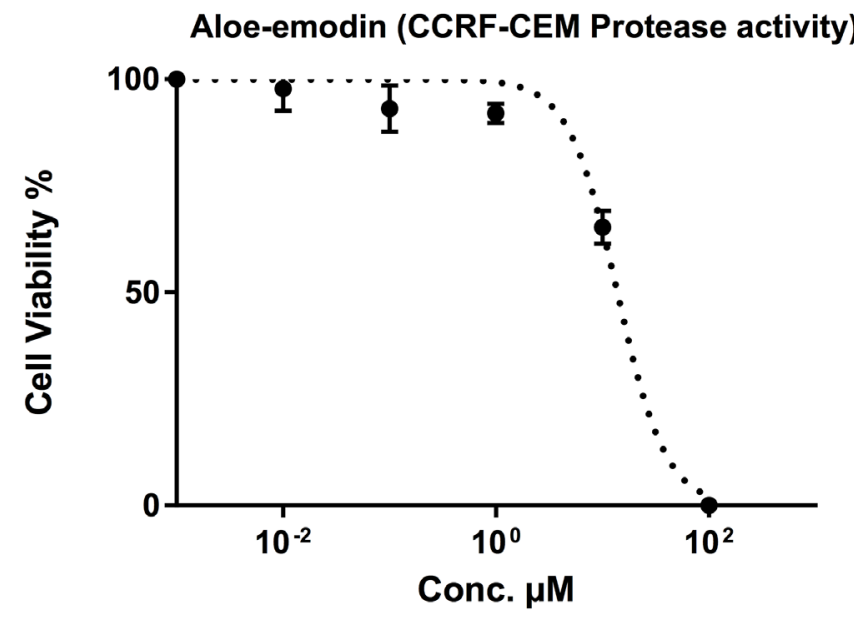

(C)

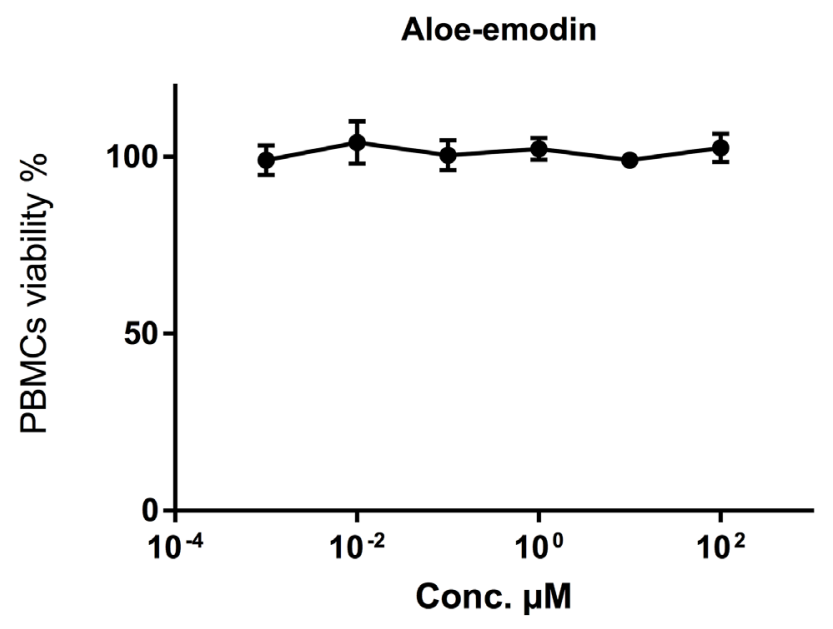

Figure 3: (A) Cytotoxicity of doxorubicin towards acute lymphoblastic cells by means for the resazurin assay. Doxorubicin was used as control drug. (B) Cytotoxicity of Aloe-emodin towards CCRF-CEM cells by means of protease viability marker assay. This assay was used as independent method for the resazurin assay. (C) Toxicity of Aloe-emodin in normal PBMC cells by means of the resazurin assay. These cells served as negative control to prove, whether or not Aloe-emodin inhibits tumor cells in a non-specific manner. 
Table 1: Validation of microarray-based gene expressions by real-time reverse transcription-PCR

\begin{tabular}{lcc}
\hline Gene name & Microarray data $\left(\right.$ FC) $^{*}$ & qPCR data $\left(\right.$ FC) $^{*}$ \\
\hline DUSP6 & 2.403 & 1.40 \\
HHEX & 2.321 & 2.23 \\
MCMDC2 & -2.227 & -2.47 \\
CRCP & -2.219 & -2.63 \\
\hline
\end{tabular}

$\mathrm{R}$ value $=0.989$ (Correlation coefficient of mRNA expression values between microarray and qPCR was determined by Pearson correlation test).

${ }^{*} \mathrm{FC}$ : Fold change.

(A)

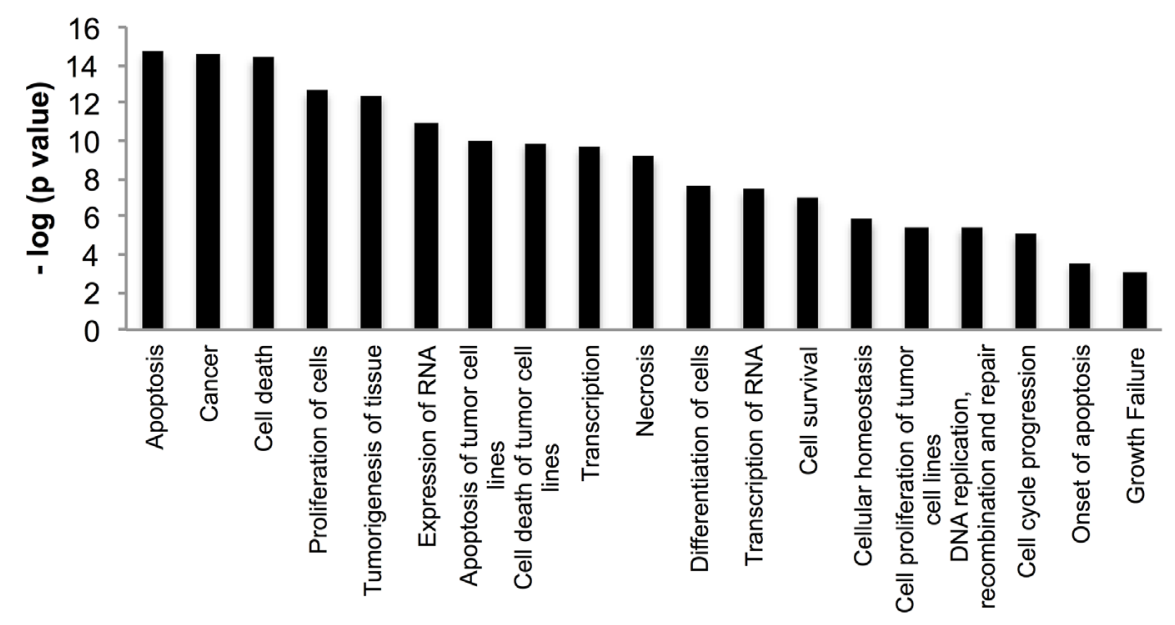

(B)

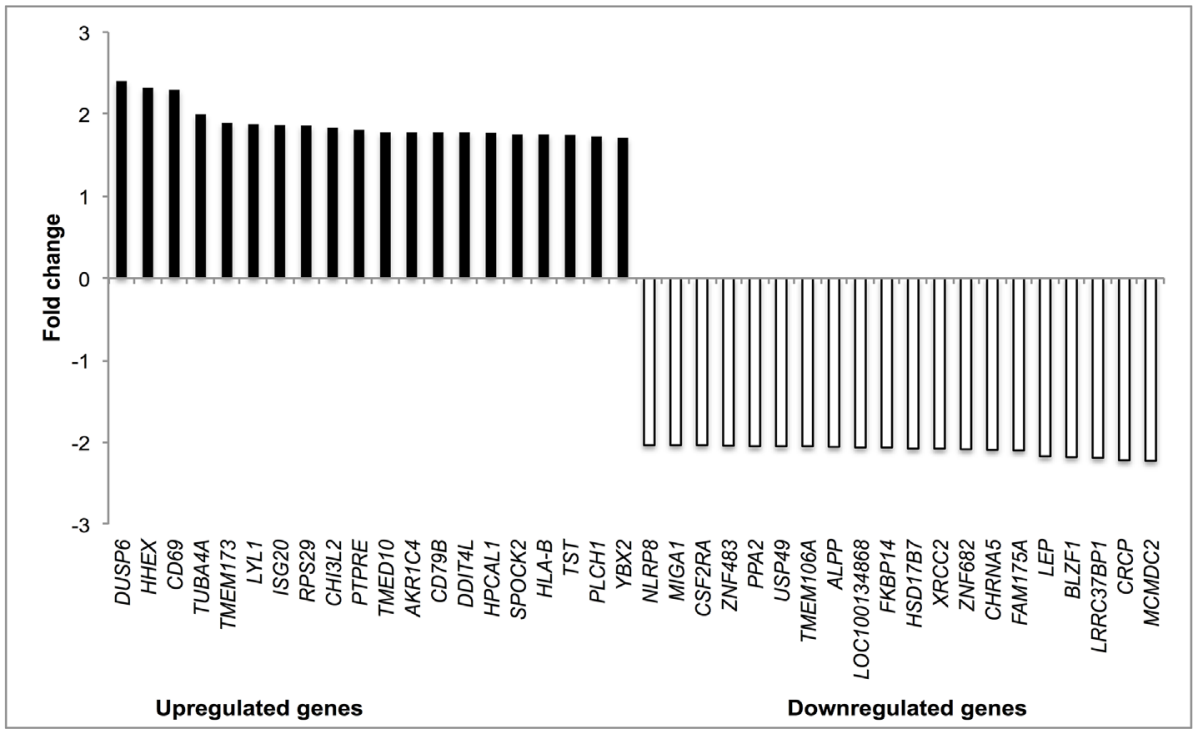

Figure 4: Microarray-based mRNA expression profiling. (A) Top cellular functions of the most upregulated and downregulated genes of CCRF-CEM cells treated with Aloe-emodin for $48 \mathrm{~h}$ identified by Ingenuity Pathway Analysis. (B) Top up- and downregulated genes in CCRF-CEM leukemia cells upon treatment with Aloe-emodin for $48 \mathrm{~h}$. 
deregulated by Aloe-emodin. Therefore, we investigated whether Aloe-emodin may cause cell cycle arrest. We treated CCRF-CEM cells with 0.5-, 1-, 2- and 4-fold $\mathrm{IC}_{50}$ of Aloe-emodin for 6, 24, 48 and $72 \mathrm{~h}$, respectively. Indeed, the cells showed a clear arrest in the S-phase of the cell cycle upon treatment for $24 \mathrm{~h}$ with the 4 -fold $\mathrm{IC}_{50}$ of Aloe-emodin (Figure 7). Doxorubicin was used as positive control. Treatment with $0.01 \mu \mathrm{M}$ and $0.1 \mu \mathrm{M}$ doxorubicin for $24 \mathrm{~h}$ induced both S- and G2/M-arrest (Figure 7).
The S-phase arrest induced by Aloe-emodin may be a consequence of oxidative stress and DNA damage.

\section{Measurement of mitochondrial membrane potential}

DNA damage causes apoptosis [28]. Numerous apoptosis-regulating genes were deregulated in the microarray experiments, which represents another clue for apoptosis
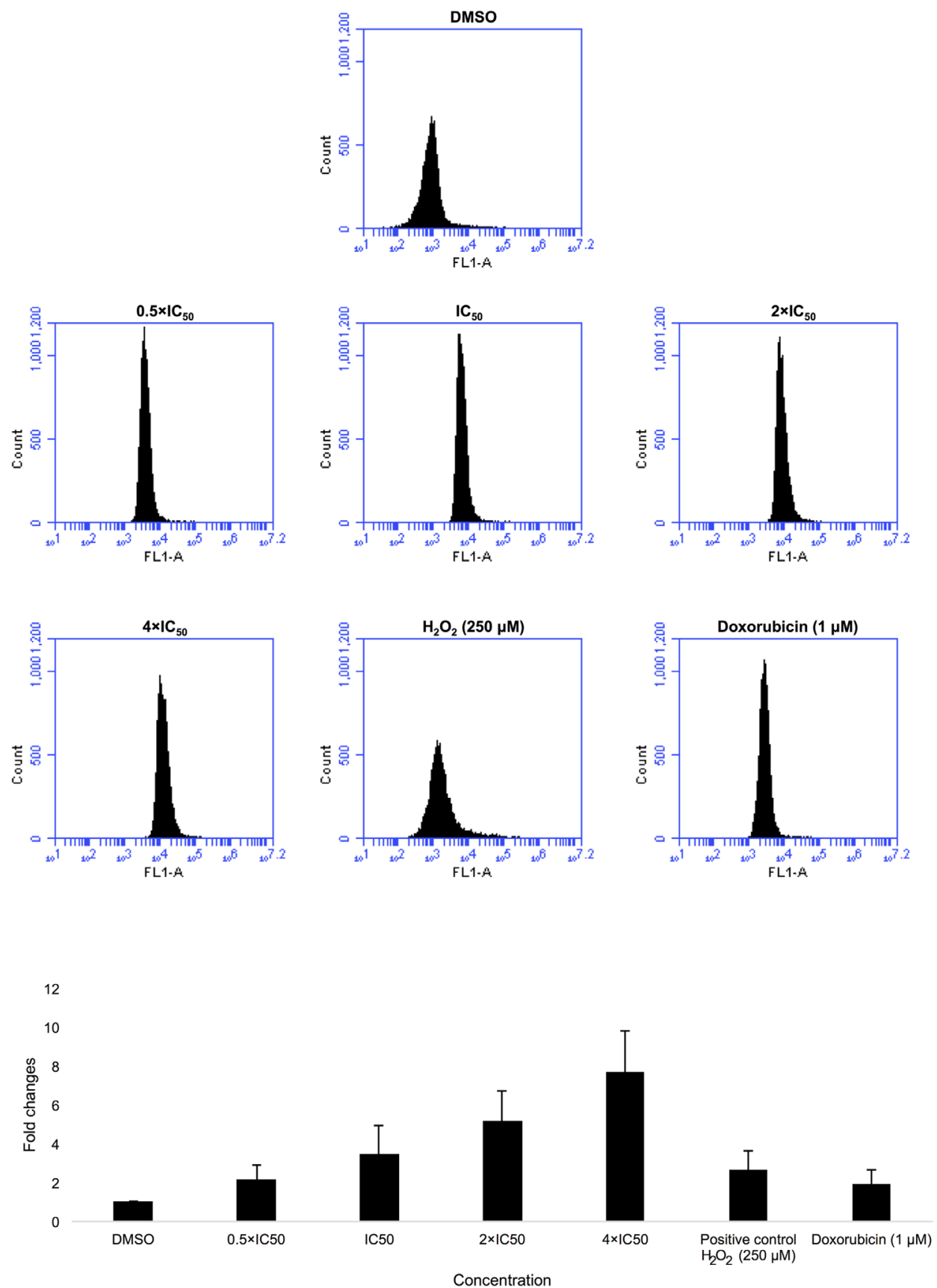

Figure 5: Induction of ROS level in CCRF-CEM cells after treatment with 0,5-, 1-, 2- and 4-fold IC 50 $_{\text {oloe-emodin. }}$ DMSO has been used as negative control, doxorubicin $(1 \mu \mathrm{M})$ and $\mathrm{H}_{2} \mathrm{O}_{2}(250 \mu \mathrm{M})$ as positive controls for $1 \mathrm{~h}$ and statistical quantification of ROS level. Mean values \pm SD of three independent experiments are shown. 


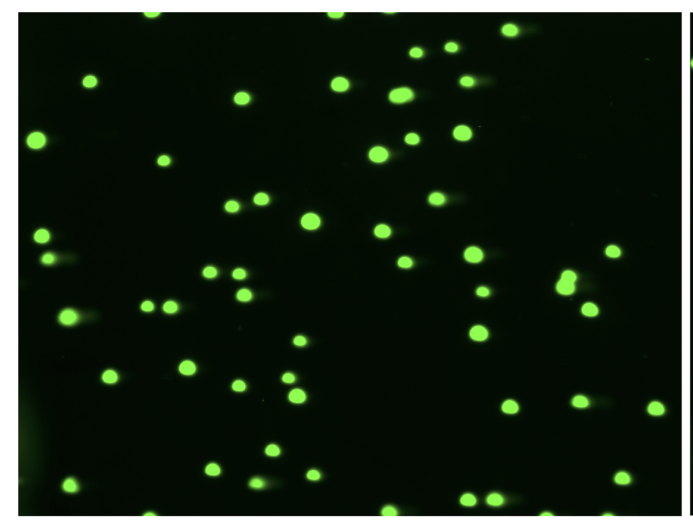

Control

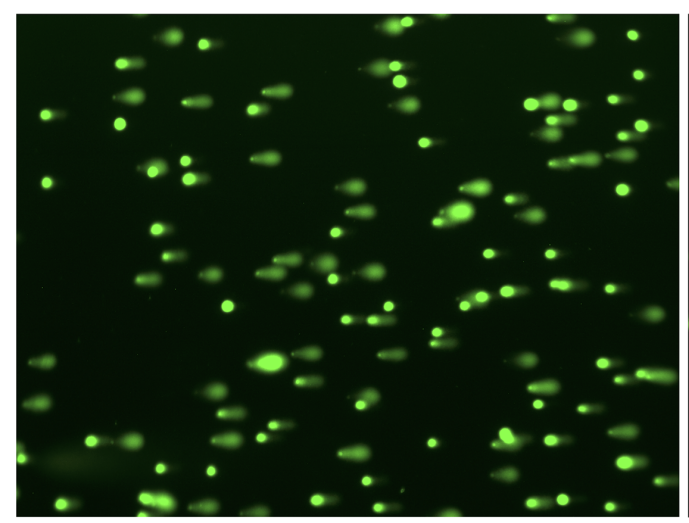

$2 \times \mathrm{IC}_{50}$

OpenComet Scoring

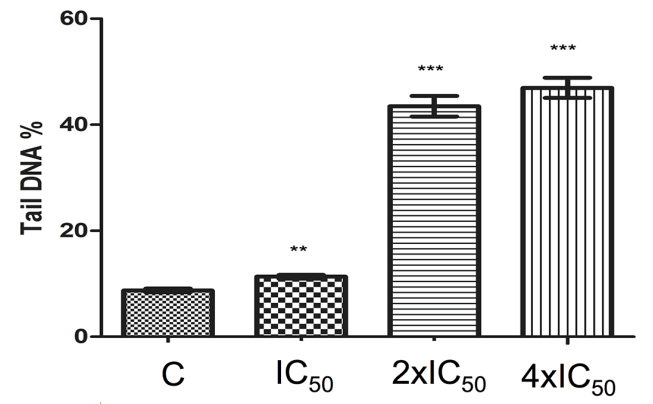

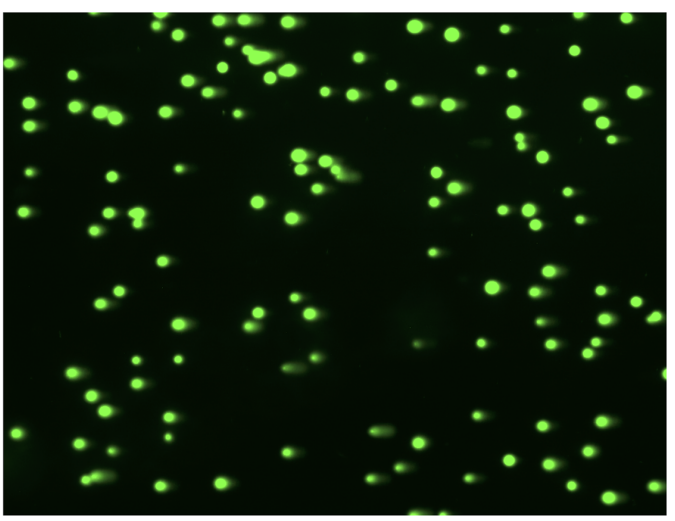

$\mathrm{IC}_{50}$

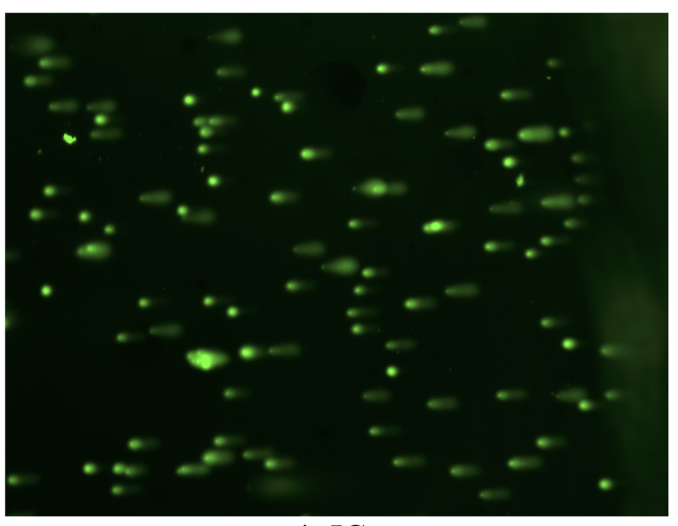

$4 \times \mathrm{IC}_{50}$

OpenComet Scoring

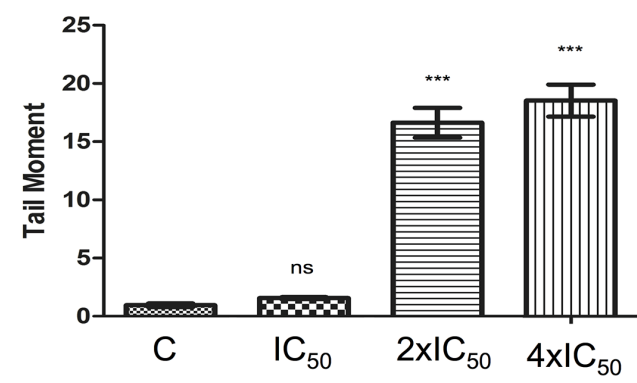

OpenComet Scoring

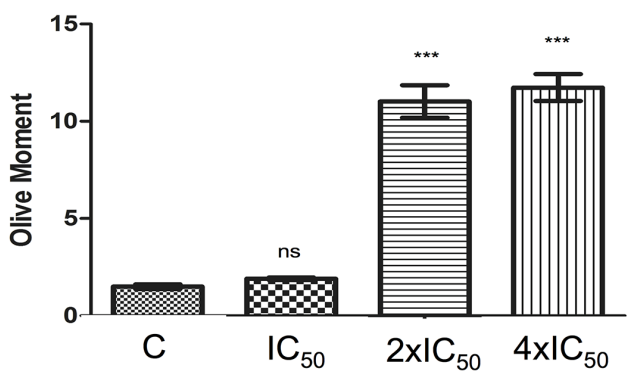

Figure 6: Induction of DNA damage by Aloe-emodin in CCRF-CEM cells. Cells were incubated with different concentration of Aloe-emodin for $24 \mathrm{~h}$. DNA damage was measured by the Comet assay. Representative pictures were shown above. Three parameters were detected including tail DNA \%, tail moment and olive moment. Tail and olive tail movement were presented in arbitrary units. Results were presented as mean \pm SEM of at least 50 cells for each. $n s$ not significant, ${ }^{* *} p<0.005 ;{ }^{* * * *} p<0.0001$ as compared to control cells. ${ }^{*} P<0.05$ compared with DMSO. Mean values \pm SEM of three independent experiments are shown. 
induction following Aloe-emodin exposure. An early event in mitochondria-driven apoptosis is the breakdown of the mitochondrial membrane potential (MMP) [29, 30]. Mitochondria control cell death by releasing cytochrome $c$ to the cytosol and followed by activating caspases [31].

We analyzed MMP alterations in CCRF-CEM cells. Therefore, we treated the cells with 1-, 2- and 4-fold $\mathrm{IC}_{50}$ of Aloe-emodin, respectively, and incubated for 24 and 48 h. Doxorubicin $(0.001,0.01,0.1$ and $1 \mu \mathrm{M})$ was tested as positive control for $48 \mathrm{~h}$. CCRF-CEM cells stained with the MMP-specific dye JC-1 revealed a shift from red to green fluorescence following treatment with 2- and 4-fold $\mathrm{IC}_{50}$ of Aloe-emodin (Figure 8A, 8B, 8D and 8E) and 0.01, 0.1 , and $1 \mu \mathrm{M}$ doxorubicin for $48 \mathrm{~h}$ (Figure $8 \mathrm{C}$ and $8 \mathrm{~F}$ ) indicating MMP depolarization.

\section{Detection of apoptosis and necrosis}

We performed annexin V/PI staining to detect apoptotic or necrotic cell death in CCRF-CEM cells. The gated cells showed different populations corresponding to viable and non-apoptotic (annexin V-PI-), early (annexin $\mathrm{V}+\mathrm{PI}-$ ), and late apoptotic as well as early (annexin $\mathrm{V}+\mathrm{PI}+$ ) and late necrotic (annexin $\mathrm{V}-\mathrm{PI}+$ ) cells. Doxorubicin inclined late apoptosis and early necrosis after treatment with $0.1 \mu \mathrm{M}$ or late necrosis after treatment with $1 \mu \mathrm{M}$ for $72 \mathrm{~h}$ (Figure 9). Aloe-emodin induced early and late apoptosis as well as early and late necrosis after treatment with the 4 -fold $\mathrm{IC}_{50}$ for $72 \mathrm{~h}$ or early and late apoptosis as well as early and late necrosis after treatment with 2-or 4-fold $\mathrm{IC}_{50}$ for $96 \mathrm{~h}$ (Figure 9).
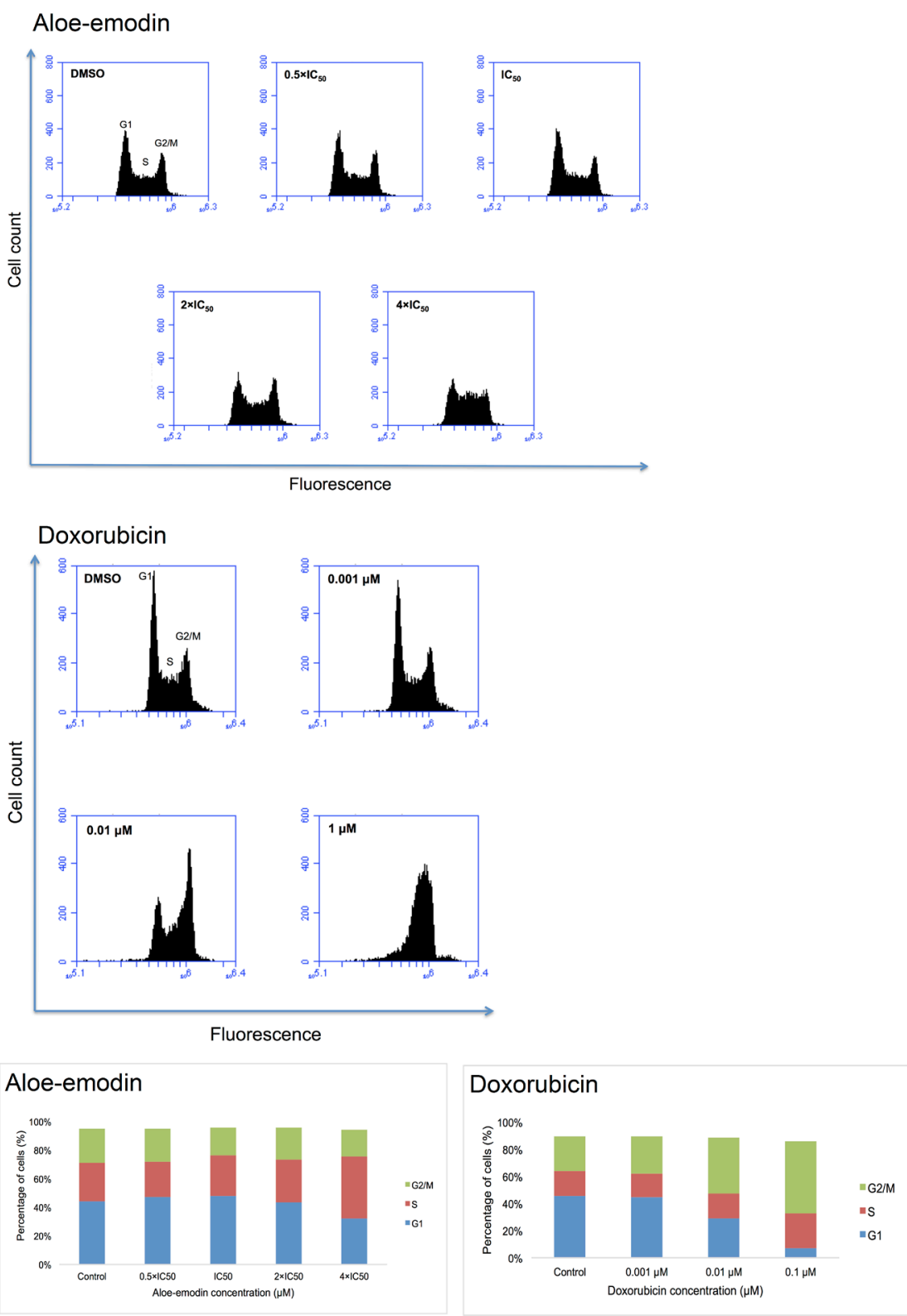

Figure 7: DNA histograms and cell cycle distribution of CCRF-CEM cells treated with indicated concentrations of Aloe-emodin and doxorubicin, respectively for $24 \mathrm{~h}$. 


\section{(A)}
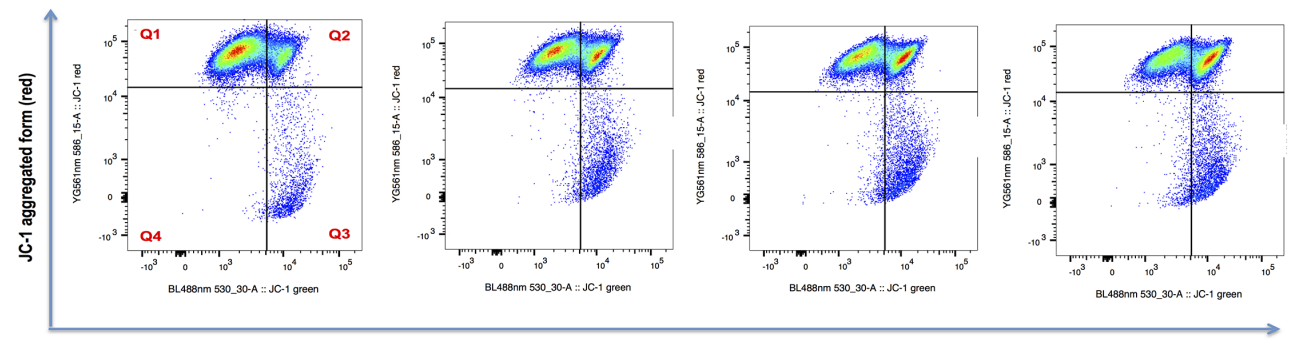

(B)

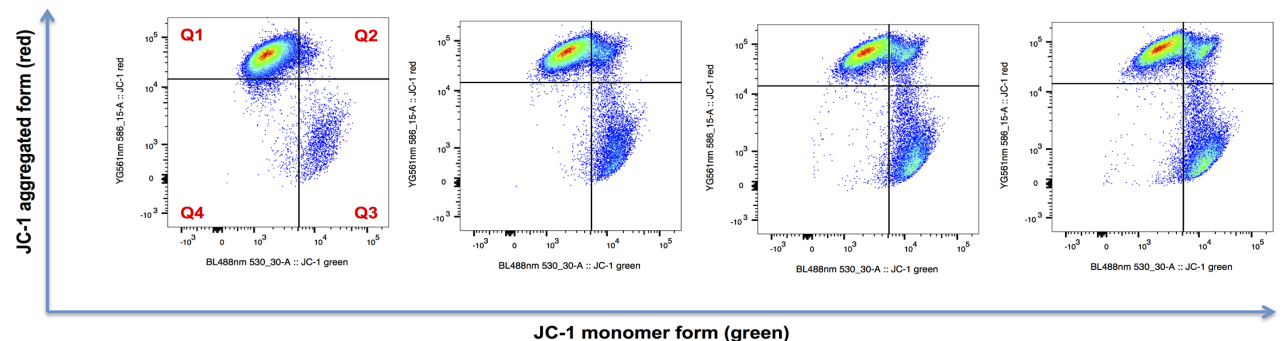

(C)

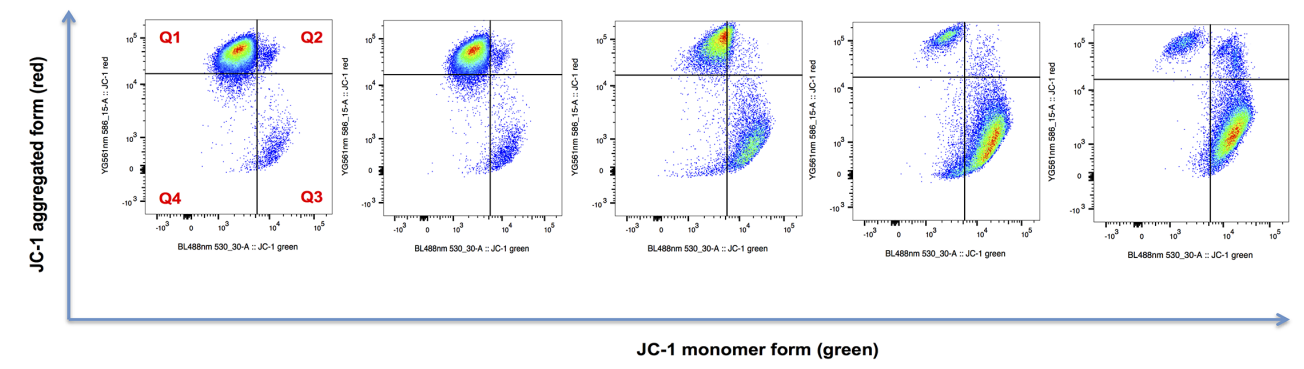

(D)

(E)
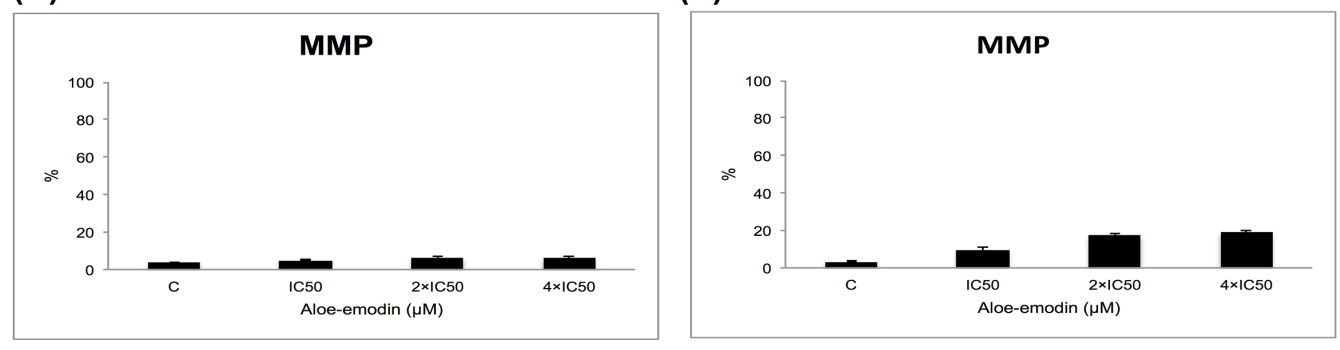

(F)

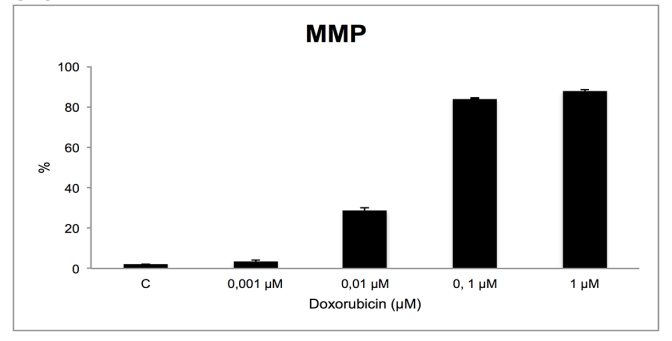

Figure 8: Disruption of the mitochondrial membrane potential by Aloe-emodin and doxorubicin, respectively in CCRF-CEM cells. Cells were treated with or without DMSO as negative control and 1-, 2- and 4-fold $\mathrm{IC}_{50}$ of Aloe-emodin, respectively for $24 \mathrm{~h} \mathrm{(A)} \mathrm{or} \mathrm{for} 48 \mathrm{~h}$ (B) or with $0.001,0.01,0.1$ and $1 \mu \mathrm{M}$ doxorubicin for $48 \mathrm{~h}$ as positive control (C) and stained by JC-1. Intact cells mainly displayed the J-aggregated form with red fluorescence (Q1) and cells with loss of MMP showed JC-1 monomers with green fluorescence (Q3). Statistical results of the cell population in Q3, which was defined as disruption of mitochondrial membrane potential with Aloe-emodin treatment for $24 \mathrm{~h}$ (D), $48 \mathrm{~h}$ (E) or doxorubicin treatment for $48 \mathrm{~h}$ (F), respectively. Mean values $\pm \mathrm{SD}$ of three independent experiments are shown. 
(A)
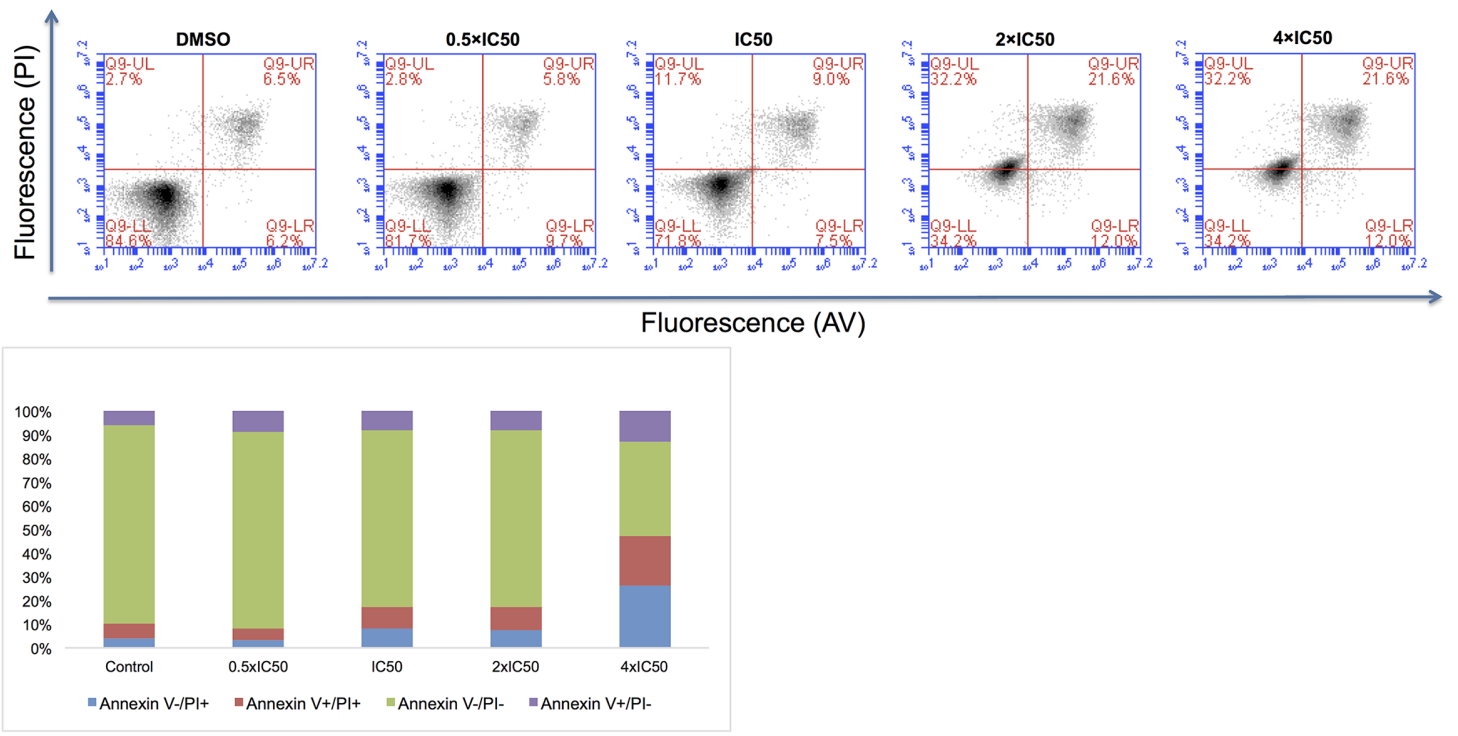

(B)
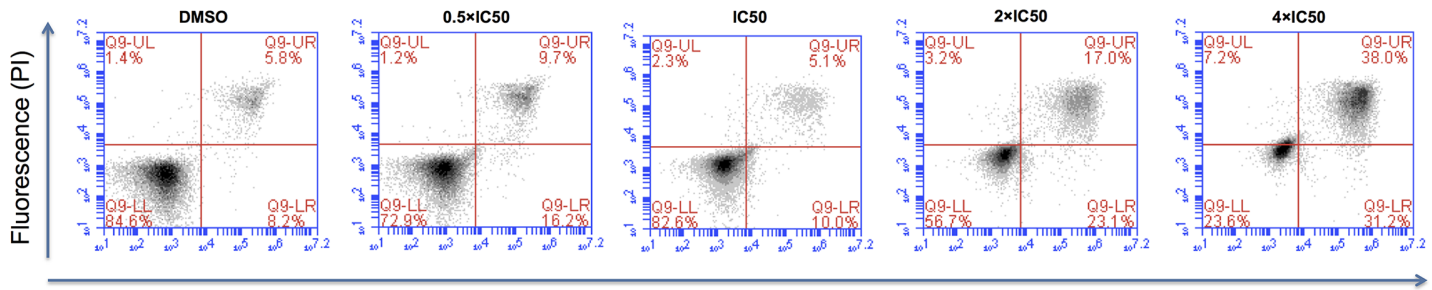

Fluorescence (AV)

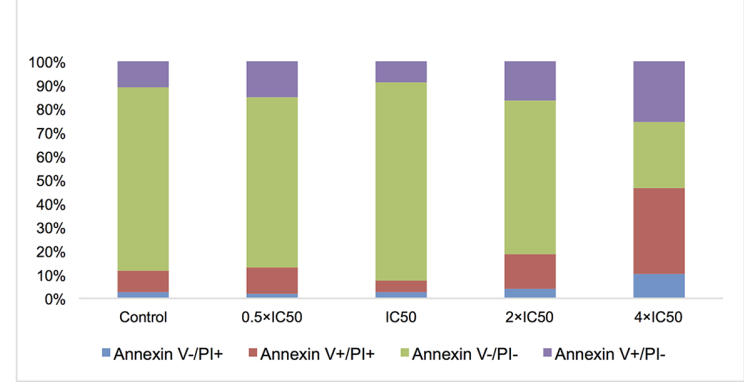

(C)
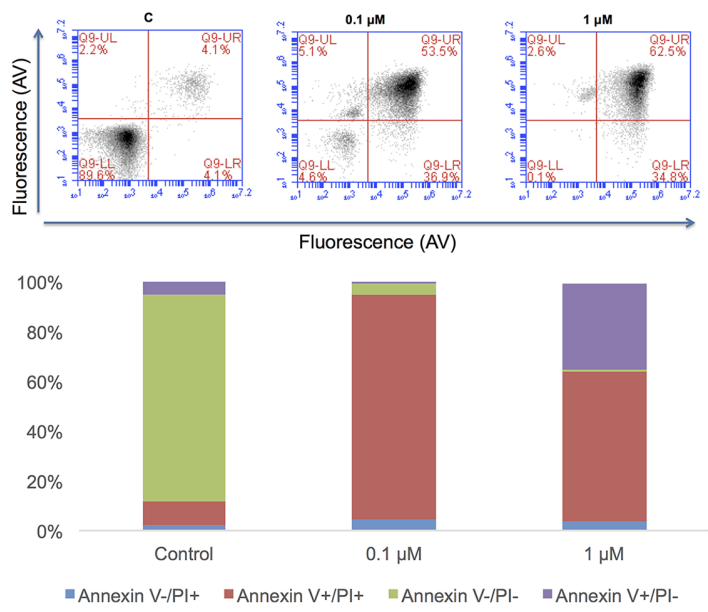

Figure 9: Apoptosis effect in CCRF-CEM cells of Aloe-emodin for $72 \mathrm{~h} \mathrm{(A)} \mathrm{and} 96 \mathrm{~h}$ (B) and of doxorubicin for $72 \mathrm{~h} \mathrm{(C).}$ 
Table 2: Separation of clusters of NCI cell line panel obtained by hierarchical cluster analysis shown in Figure 10 in comparison to drug sensitivity ${ }^{\mathrm{a}}$

\begin{tabular}{lcccc}
\hline & Partition & Cluster 1 & Cluster 2 & Cluster 3 \\
\hline Sensitive & $<-4.35 \mathrm{M}$ & 0 & 8 & 12 \\
Resistant & $>-4.35 \mathrm{M}$ & 16 & 5 & 0 \\
chi-square test: $\mathrm{p}=5.90 \times 10^{-7}$ & & & & \\
\hline
\end{tabular}

${ }^{a}$ The median $\log _{10} \mathrm{IC}_{50}$ value $(-4.35 \mathrm{M})$ for each compound was used as a cutoff to separate tumor cell lines as being "sensitive" or "resistant".

\section{COMPARE and hierarchical cluster analyses of transcriptome-wide mRNA expression in untreated cell lines}

The mRNA microarray data of the NCI tumor cell line panel have been deposited at the NCI website (http:// dtp.cancer.gov/databases_tools/default.htm). We applied COMPARE analyses to generate rank-ordered lists of genes expressed in the NCI cell lines. As previously described [32, 33], every gene of the NCI microarray database was ranked for similarity of its mRNA expression to the $\log _{10} \mathrm{IC}_{50}$ values for the compound under investigation (i.e., Aloe-emodin). A scale index of correlation coefficients ( $R$-values) was created to derive COMPARE rankings.

The mRNA expression data of the cell lines were subjected to hierarchical cluster analysis. Each three main cluster branches appeared in the dendrogram for Aloeemodin (Figure 10). We examined the distribution of sensitive or resistant cells to Aloe-emodin by using the $\chi^{2}$ test.

To perform the $\chi^{2}$-test, we defined the cell lines as being sensitive or resistant to Aloe-emodin. The $\log _{10} \mathrm{IC}_{50}$ value of Aloe-emodin for all cell lines ( -4.35 M) served as cut-off threshold. Cell lines with $\log _{10} \mathrm{IC}_{50}$ values below this threshold were defined as sensitive,

1 \begin{tabular}{|ll|}
\hline Cell line & Tumor type \\
\hline TK-10 & Renal Ca \\
CAKI-1 & Renal Ca \\
OVCAR-4 & Ovarian Ca \\
SF-268 & Brain tumor \\
NCl-H23 & Lung Ca \\
SK-OV-3 & Ovarian Ca \\
HOP-92 & Lung Ca \\
RXF 393 & Renal Ca \\
U251 & Brain tumor \\
SNB-75 & Brain tumor \\
A498 & Renal Ca \\
SNB-19 & Brain tumor \\
SF-295 & Brain tumor \\
NCI-H226 & Lung Ca \\
OVCAR-5 & Ovarian Ca \\
HOP-62 & Lung Ca \\
\hline
\end{tabular}

3 \begin{tabular}{|ll|}
\hline Cell line & Tumor type \\
\hline NCl-H522 & Lung Ca \\
HL6O(TB) & Leukemia \\
SK-MEL-5 & Melanoma \\
SW-620 & Colon Ca \\
HCT-15 & Colon Ca \\
KM12 & Colon Ca \\
HCT-116 & Colon Ca \\
COLO 205 & Colon Ca \\
NCl-H460 & Lung Ca \\
RPMI-8226 & Leukemia \\
MOLT-4 & Leukemia \\
CCRF-CEM & Leukemia \\
\hline
\end{tabular}

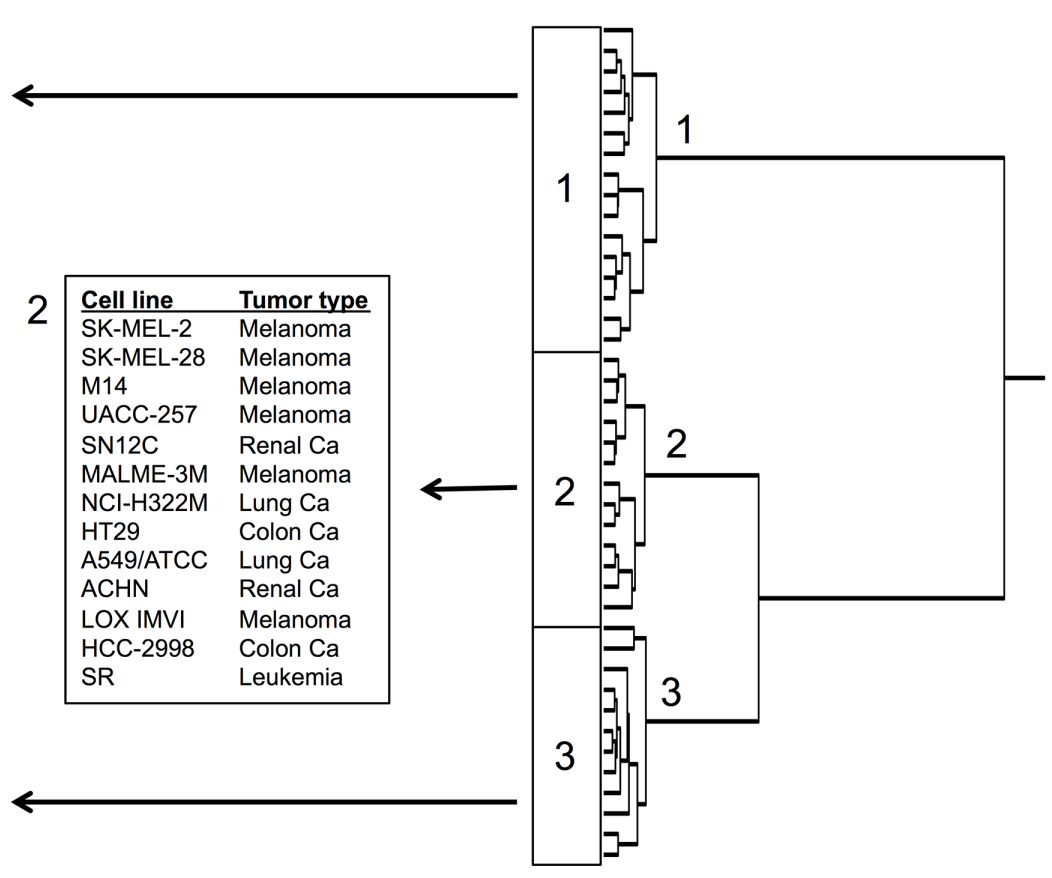

Figure 10: Hierarchical cluster analysis of microarray-based mRNA expression of genes for Aloe-emodin. The dendrograms show the clustering of the NCI cell line panel according to the degrees of relatedness between cell lines. 
cell lines above this threshold as resistant. Cluster 1 and cluster 3 contained mainly sensitive and resistant cell lines, respectively, whereas cluster 2 was of a mixed type. This distribution of sensitive and resistant cell lines was statistically significant ( $\chi^{2}$ test, $P=5.90 \times 10^{-7}$; Table 2 ). This implies that the expression of this set of genes caused dendrogram branching in a way that gene expression predicted the inherent cellular responsiveness to Aloeemodin in a statistically significant manner.

The analysis of microarray data showed that genes involved in signal transduction, apoptosis, nucleic acid metabolism etc. seemed to have a role for inherent resistance responsiveness of tumor cells towards Aloeemodin (Table 3).

\section{DISCUSSION}

In the present investigation, we analyzed the modes of action and determinants of resistance of cancer cells to chemical constituents of $R$. acetosella with special emphasis to Aloe-emodin. The isolation of phytochemicals from medicinal plants represents a state-of-the-art procedure in pharmacognosy. $R$. acetosella contains anthraquinones, flavonoids and other phenolic compounds. We decided to focus on anthraquinones because of their striking chemical similarity to anthracyclines as clinically well-established anticancer drugs since decades. Because of this chemical relationship, we suggested cytotoxic acivity against cancer cells.

Additionally, the cytotoxic activity of anthaquinones provides a rationale explanation that Rumex species have been traditionally used to treat cancer [21, 22, 34]. A major anthraquinone aglycone of Rumex and other genera (e.g. Aloe, Rheum and Rhamnus) is Aloe-emodin [35, 36]. A main motivation to investigate the molecular mechanisms of Aloe-emodin was its activity against drug-resistant tumor cells. There are hundreds, if not thousands of cytotoxic phytochemicals from medicinal plants, which never reached clinical application. What is really needed to our opinion, are novel substances that are better than the established anticancer drugs. Aloe-emodin is not only outstanding to suppress tumor growth in vivo as previously demonstrated [37-39], but this compound was also able to kill tumor cells, which are resistant to standard anticancer agents as shown here. The development of resistance to anticancer drugs poses a major obstacle to successful chemotherapy, and innumerous patients died because of their refractory and resistant tumors. For this reason, there is a high demand for novel compounds with activity against otherwise drug-resistant tumors. Aloe-emodin may have the potential as new drug, because of its property to kill otherwise refractory.

We focused on resistance phenotypes, which are characterized by broad cross-resistance not only towards single, but also towards many chemically and functionally different cytostatic drugs. These multiple drug resistance
(MDR) phenomena are frequently mediated by drug efflux pumps of the ATP-binding cassette (ABC) type as well as activated oncogenes or inactivated tumor suppressor genes. We have chosen three $\mathrm{ABC}$-transporters, i.e., P-glycoprotein (MDR1/ABCB1) and breast cancer resistance protein (BCRP/ABCG2) as well-known MDRmechanisms and $\mathrm{ABCB} 5$ as novel efflux transporter relevant for cancer stem-like cells. Oncogenes and tumor suppressor genes do not only contribute to carcinogenesis, but also confer drug resistance [40]. We selected the epidermal growth factor receptor (EGFR) and the tumor suppressor gene p53 for our investigations.

After isolation of several anthraquinones, we concentrated on Aloe-emodin as the most cytotoxic compound in our investigation. Interestingly, HCT116 $\left(\mathrm{p} 53^{-/}\right.$) cells even exhibited collateral sensitivity to Aloeemodin. In P-glycoprotein-overexpressing cells, collateral sensitivty has been explained by futile cycles of ATP cleavage by the efflux transporter and transient depletion of cellular ATP stores ultimately leading to cell death [41]. However, the underlying mechanisms of collateral sensitivity in p53-knockout cells is completely unknown as yet and deserves further investigation.

The analysis of resistant cell lines provided us first clues on the mechanisms of action of Aloe-emodin. However, cell lines of different tumor types may respond differently to Aloe-emodin according to their individual gene expression profiles. Therefore, we wanted to find out, which tumor types reacted better or worse to Aloe-emodin. To address this question, we performed COMPARE and hierarchical cluster analysis of transcriptome-wide microarray-based mRNA hybridizations in a panel of 60 tumor cell lines of DTP (NCI, USA) (http: dtp.cancer. gov). DTP assessed to more than 88.000 pure compounds and more than 34.000 crude extracts against the panel of 60 human tumor cell lines as of yet. Interestingly, the pattern of cellular sensitivity and resistance of these cell lines to established anticancer drugs as well as investigational cytotoxic compounds correlated with their molecular target expression [42, 43]. This approach has been frequently applied by us and others in recent years [44-48]. Here, we used this approach to identify genes, whose expression correlated with sensitivity or resistance of the cell lines with Aloe-emodin.

An intriguing result of hierarchical cluster analyses was that a set of only 40 genes out of the entire transcriptome was sufficient to determine, whether a cell line was sensitive or rather resistant to Aloe-emodin. This is a remarkable result, because the $\mathrm{IC}_{50}$ values of the cell lines had not been prior included into the calculations for the cluster analyses. The implication of this result is that sensitivity or resistance of a drug in tumor cells can be predicted based on the gene expression profile alone. It can be speculated that such an approach could be translated to the clinical setting for the individualized treatment of cancer patients. 
Table 3: Correlation of constitutive mRNA expression of genes identified by COMPARE analyses with the $\log _{10} I_{50}$ values of Aloe-emodin for the NCI tumor cell lines

\begin{tabular}{|c|c|c|c|c|c|}
\hline $\begin{array}{l}\text { COMPARE } \\
\text { coefficient }\end{array}$ & $\begin{array}{l}\text { Experimental } \\
\text { ID }\end{array}$ & $\begin{array}{c}\text { GeneBank } \\
\text { accession }\end{array}$ & $\begin{array}{c}\text { Gene } \\
\text { symbol }\end{array}$ & Name & Function \\
\hline 0.641 & 29457 & Y00978 & $D L A T$ & $\begin{array}{l}\text { Dihydrolipoamide } \\
\text { S-acetyltransferase }\end{array}$ & $\begin{array}{c}\text { Transferase activity; links the } \\
\text { glycolytic pathway to the tricarboxylic } \\
\text { cycle }\end{array}$ \\
\hline 0.614 & 23142 & D50929 & EIF3A & $\begin{array}{l}\text { Eukaryotic translation initiation } \\
\text { factor 3, subunit A }\end{array}$ & $\begin{array}{l}\text { Involved in apoptosis of synovial } \\
\text { fibroblasts }\end{array}$ \\
\hline 0.613 & 31751 & AF047042 & $C S$ & Citrate synthase & $\begin{array}{c}\text { Poly(A) RNA binding and citrate } \\
\text { (Si)-synthase activity; mitochondrial } \\
\text { targeting }\end{array}$ \\
\hline 0.584 & 25141 & D21851 & $L A R S 2$ & $\begin{array}{l}\text { Leucyl-tRNA synthetase } 2, \\
\text { mitochondrial }\end{array}$ & $\begin{array}{l}\text { Nucleotide binding and aminoacyl- } \\
\text { tRNA editing activity }\end{array}$ \\
\hline 0.581 & 31188 & AF081280 & NPM3 & Nucleophosmin/nucleoplasmin 3 & Poly(A) RNA binding \\
\hline 0.57 & 24945 & S79522 & $R P S 27 A$ & Ribosomal protein $\mathrm{S} 27 \mathrm{a}$ & $\begin{array}{l}\text { Poly(A) RNA binding and structural } \\
\text { constituent of ribosome }\end{array}$ \\
\hline 0.561 & 22197 & AB011136 & KIAA0564 & KIAA0564 & ATPase activity \\
\hline 0.558 & 25753 & AB018307 & SUPT7L & $\begin{array}{c}\text { Suppressor of Ty } 7 \text { (S. cerevisiae)- } \\
\text { like }\end{array}$ & $\begin{array}{l}\text { Transcription coactivator activity } \\
\text { and histone acetyltransferase; role in } \\
\text { chromatin activation, transcriptional } \\
\text { regulation, and DNA damage repair }\end{array}$ \\
\hline 0.551 & 31083 & D50925 & PASK & $\begin{array}{l}\text { PAS domain containing serine/ } \\
\text { threonine kinase }\end{array}$ & $\begin{array}{c}\text { Transferase activity; protein tyrosine } \\
\text { kinase activity }\end{array}$ \\
\hline 0.545 & 28659 & D26488 & WDR43 & WD repeat domain 43 & Poly(A) RNA binding and binding \\
\hline 0.533 & 22297 & X79563 & $\operatorname{RPS} 21$ & Ribosomal protein S21 & $\begin{array}{l}\text { Poly(A) RNA binding and protein } \\
\text { N-terminus binding }\end{array}$ \\
\hline 0.524 & 30065 & U94703 & POLG2 & $\begin{array}{l}\text { Polymerase (DNA directed), } \gamma 2, \\
\text { accessory subunit }\end{array}$ & $\begin{array}{l}\text { Identical protein binding and DNA- } \\
\text { directed DNA polymerase activity }\end{array}$ \\
\hline 0.523 & 23131 & AI541050 & NDUFB 8 & $\begin{array}{l}\text { NADH dehydrogenase (ubiquinone) } \\
1 \beta \text { subcomplex, } 8,19 \mathrm{kDa}\end{array}$ & $\begin{array}{l}\text { NADH dehydrogenase (ubiquinone) } \\
\text { activityand NADH dehydrogenase } \\
\text { activity }\end{array}$ \\
\hline 0.521 & 30499 & X16396 & MTHFD2 & $\begin{array}{c}\text { Methylenetetrahydrofolate } \\
\text { dehydrogenase ( } \mathrm{NADP}^{+} \text {dependent) } \\
\text { 2, methenyltetrahydrofolate } \\
\text { cyclohydrolase }\end{array}$ & $\begin{array}{l}\text { Magnesium ion binding and formate- } \\
\text { tetrahydrofolate ligase activity }\end{array}$ \\
\hline 0.516 & 29266 & D79989 & $A G A P 2$ & $\begin{array}{l}\text { ArfGAP with GTPase domain, } \\
\text { ankyrin repeat and PH domain } 2\end{array}$ & $\begin{array}{l}\text { GTP binding and GTPase activator } \\
\text { activity mediates anti-apoptotic } \\
\text { effects of nerve growth factor is } \\
\text { overexpressed in cancer cells, and } \\
\text { promotes cancer cell invasion }\end{array}$ \\
\hline 0.515 & 32195 & M92439 & $L R P P R C$ & Leucine-rich PPR-motif containing & $\begin{array}{l}\text { Poly(A) RNA binding and ubiquitin } \\
\text { protein ligase binding }\end{array}$ \\
\hline 0.514 & 25646 & AF067139 & NDUFS3 & $\begin{array}{l}\text { NADH dehydrogenase (ubiquinone) } \\
\text { Fe-S protein 3, 30kDa (NADH- } \\
\text { coenzyme Q reductase) }\end{array}$ & $\begin{array}{l}\text { Poly(A) RNA binding and ubiquitin } \\
\text { protein ligase binding; } \\
\text { transcriptional regulation of both } \\
\text { nuclear and mitochondrial genes }\end{array}$ \\
\hline 0.506 & 25108 & D80007 & PDCD11 & Programmed cell death 11 & $\begin{array}{l}\text { Nucleic acid binding and transcription } \\
\text { factor binding; required for rRNA } \\
\text { maturation and generation of } 18 \mathrm{~S} \\
\text { rRNA }\end{array}$ \\
\hline
\end{tabular}

(Continued) 


\begin{tabular}{|c|c|c|c|c|c|}
\hline $\begin{array}{l}\text { COMPARE } \\
\text { coefficient }\end{array}$ & $\begin{array}{l}\text { Experimental } \\
\text { ID }\end{array}$ & $\begin{array}{c}\text { GeneBank } \\
\text { accession }\end{array}$ & $\begin{array}{c}\text { Gene } \\
\text { symbol }\end{array}$ & Name & Function \\
\hline 0.506 & 31640 & L49380 & $S F 1$ & Splicing factor 1 & $\begin{array}{c}\text { Nucleic acid binding and RNA } \\
\text { binding; plays a role in nuclear pre- } \\
\text { mRNA retention and transcriptional } \\
\text { repression }\end{array}$ \\
\hline 0.502 & 32348 & U66615 & SMARCC1 & $\begin{array}{c}\text { SWI/SNF related, matrix } \\
\text { associated, actin dependent } \\
\text { regulator of chromatin, subfamily c, } \\
\text { member } 1\end{array}$ & $\begin{array}{l}\text { Chromatin binding and RNA } \\
\text { polymerase II core promoter proximal } \\
\text { region sequence-specific DNA binding }\end{array}$ \\
\hline-0.606 & 27140 & AL096739 & GALNT10 & $\begin{array}{c}\text { UDP-N-acetyl- } \alpha \text {-D- } \\
\text { galactosamine:polypeptide } \\
\text { N-acetylgalactosaminyltransferase } \\
10(\text { GalNAc-T10) }\end{array}$ & $\begin{array}{c}\text { Carbohydrate binding and polypeptide } \\
\mathrm{N} \text {-acetylgalactosaminyltransferase } \\
\text { activity }\end{array}$ \\
\hline-0.581 & 24659 & $\mathrm{AB} 023175$ & POFUT2 & Protein O-fucosyltransferase 2 & $\begin{array}{c}\text { Fucosyltransferase activity and } \\
\text { peptide-O-fucosyltransferase activity }\end{array}$ \\
\hline-0.547 & 28663 & AB020689 & $T B C 1 D 9$ & $\begin{array}{l}\text { TBC1 domain family, member } 9 \\
\text { (with GRAM domain) }\end{array}$ & $\begin{array}{l}\text { Calcium ion binding and GTPase } \\
\text { activator activity }\end{array}$ \\
\hline-0.546 & 24243 & AI547262 & ATP6V0E1 & $\begin{array}{l}\text { ATPase, } \mathrm{H}^{+} \text {transporting, lysosomal } \\
\quad 9 \mathrm{kDa}, \mathrm{V} 0 \text { subunit e } 1\end{array}$ & $\begin{array}{c}\text { Transporter activity and proton- } \\
\text { transporting ATPase activity, rotational } \\
\text { mechanism; encodes a component of } \\
\text { vacuolar ATPase (V-ATPase) which } \\
\text { is necessary for diverse intracellular } \\
\text { processes }\end{array}$ \\
\hline-0.545 & 32200 & Z47087 & $S K P 1$ & S-phase kinase-associated protein 1 & $\begin{array}{l}\text { Ubiquitin-protein transferase activity; } \\
\text { encodes an essential component } \\
\text { of SCF complex which mediates } \\
\text { ubiquitination of proteins involved } \\
\text { in cell cycle progression, signal } \\
\text { transduction and transcription }\end{array}$ \\
\hline-0.542 & 31737 & AA477898 & ITM2B & Integral membrane protein $2 \mathrm{~B}$ & $\begin{array}{l}\beta \text {-amyloid binding plays a regulatory } \\
\text { role in processing of } \beta \text {-amyloid A4 } \\
\text { precursor protein (APP); inhibitor of } \\
\beta \text {-amyloid peptide aggregation and } \\
\text { fibrils deposition }\end{array}$ \\
\hline-0.538 & 23424 & L07738 & CACNG1 & $\begin{array}{l}\text { Calcium channel, voltage- } \\
\text { dependent, } \gamma \text { subunit } 1\end{array}$ & $\begin{array}{l}\text { Voltage-gated calcium channel } \\
\text { activity; role in excitation-contraction } \\
\text { coupling }\end{array}$ \\
\hline-0.536 & 29496 & M88458 & KDELR2 & $\begin{array}{l}\text { KDEL (Lys-Asp-Glu-Leu) } \\
\text { endoplasmic reticulum protein } \\
\text { retention receptor } 2\end{array}$ & $\begin{array}{c}\text { ER (endoplasmic reticulum) retention } \\
\text { sequence binding and KDEL } \\
\text { (Endoplasmic Reticulum Protein } \\
\text { Retention Receptor 2) sequence } \\
\text { binding. }\end{array}$ \\
\hline-0.532 & 22897 & AF063002 & FHL1 & Four and a half LIM domains 1 & Ion channel binding \\
\hline-0.531 & 24272 & AB007144 & $D A P K 3$ & Death-associated protein kinase 3 & $\begin{array}{c}\text { Protein homodimerization activity and } \\
\text { transferase activity; role in induction } \\
\text { of apoptosis }\end{array}$ \\
\hline-0.531 & 30005 & AB020640 & CAMTA1 & $\begin{array}{c}\text { Calmodulin binding transcription } \\
\text { activator } 1\end{array}$ & $\begin{array}{l}\text { Transcriptional activator; may act as } \\
\text { tumor suppressor }\end{array}$ \\
\hline
\end{tabular}

(Continued) 


\begin{tabular}{|c|c|c|c|c|c|}
\hline $\begin{array}{l}\text { COMPARE } \\
\text { coefficient }\end{array}$ & $\begin{array}{c}\text { Experimental } \\
\text { ID }\end{array}$ & $\begin{array}{c}\text { GeneBank } \\
\text { accession }\end{array}$ & $\begin{array}{c}\text { Gene } \\
\text { symbol }\end{array}$ & Name & Function \\
\hline-0.527 & 29746 & D86983 & $P X D N$ & $\begin{array}{l}\text { Peroxidasin homologue } \\
\text { (Drosophila) }\end{array}$ & $\begin{array}{l}\text { Heme binding and peroxidase } \\
\text { activity; involved in extracellular } \\
\text { matrix formation; may function in } \\
\text { the physiological and pathological } \\
\text { fibrogenic response in fibrotic kidney }\end{array}$ \\
\hline-0.526 & 29587 & AL049957 & CD59 & $\begin{array}{l}\text { CD59 molecule, complement } \\
\text { regulatory protein }\end{array}$ & $\begin{array}{l}\text { Complement binding; encodes a cell } \\
\text { surface glycoprotein that regulates } \\
\text { complement-mediated cell lysis; } \\
\text { involved in lymphocyte signal } \\
\text { transduction }\end{array}$ \\
\hline-0.524 & 22562 & M83088 & PGM1 & Phosphoglucomutase 1 & $\begin{array}{l}\text { Magnesium ion binding and } \\
\text { phosphoglucomutase activity; } \\
\text { participates in both breakdown and } \\
\text { synthesis of glucose }\end{array}$ \\
\hline-0.523 & 20761 & L25081 & RHOC & $\begin{array}{c}\text { Ras homolog gene family, member } \\
\text { C }\end{array}$ & $\begin{array}{l}\text { GTP binding and signal transducer } \\
\text { activity; overexpression is associated } \\
\text { with tumor cell proliferation and } \\
\text { metastasis }\end{array}$ \\
\hline-0.522 & 30218 & D63475 & $A P 2 M 1$ & $\begin{array}{l}\text { Adaptor-related protein complex } 2 \text {, } \\
\qquad \mu 1 \text { subunit }\end{array}$ & $\begin{array}{l}\text { Transporter activity and low-density } \\
\text { lipoprotein particle receptor binding }\end{array}$ \\
\hline-0.522 & 26170 & H93123 & $V A M P 3$ & $\begin{array}{l}\text { Vesicle-associated membrane } \\
\text { protein } 3 \text { (cellubrevin) }\end{array}$ & $\begin{array}{l}\text { SNARE binding and syntaxin-1 } \\
\text { binding }\end{array}$ \\
\hline-0.516 & 20862 & L77886 & PTPRK & $\begin{array}{l}\text { Protein tyrosine phosphatase, } \\
\text { receptor type, } \mathrm{K}\end{array}$ & $\begin{array}{l}\text { Protein kinase binding and protein } \\
\text { tyrosine phosphatase activity; } \\
\text { regulation of processes involving cell } \\
\text { contact and adhesion (growth control, } \\
\text { invasion, and metastasis) }\end{array}$ \\
\hline-0.511 & 32199 & AL096879 & TMEM184B & Transmembrane protein 184B & $\begin{array}{l}\text { May activate the MAP kinase signaling } \\
\text { pathway }\end{array}$ \\
\hline-0.51 & 27189 & Z24727 & TPM1 & Tropomyosin $1(\alpha)$ & $\begin{array}{l}\text { Actin binding and cytoskeletal protein } \\
\text { binding; suppresses anchorage- } \\
\text { independent growth }\end{array}$ \\
\hline
\end{tabular}

Positive correlation coefficients indicate direct correlations to $\log _{10} \mathrm{IC}_{50}$ values, negative ones indicate inverse correlations. Information on gene functions was taken from the OMIM database (NCBI, Bethesda, MD, USA) [78] and from the GeneCards database of the Weizman Institute of Science (Rehovot, Israel) [79].

The following scenario can be envisaged: If a tumor is resistant to most standard drugs, gene expression profiling could help to predict, which cytotoxic phytochemical is still active in this tumor. Before clinical treatment with Aloe-emodin can be realistically considered for routine treatment, robust gene expression profiles of patients' biopsies have to be determined that reliably predict tumor sensitivity towards Aloe-emodin. The present paper may open avenues for cancer precision medicine with Aloe-emodin once this compound could be clinically established. More analyses are necessary before this concept can be realized in clinical everyday practice. Nevertheless, our results represent a proofof-principle that natural products in general represent a promising resouce for novel anicancer drugs, which might be implemented in future treatment strategies.
Two conditions are necessary to realize this concept of individualized therapy with natural procuts from medicinal plants (1) the panel of available cytotoxic phytochemicals should be large enough to choose the right compound for the right patient; (2) therapeutically relevant genes have to be separated from non-relevant background noise in the gene expression profile. It is a frequently made observation that many genes that are deregulated upon drug treatment do not bear functional relevance for the corresponding drug, but are just concomitant noncausative alterations. Recently commercial low density arrays have been marketed that carry only genes with causative relevance for the response of tumors to standard chemotherapy. Although gene expression profiles have been generated in cell lines for many phytochemicals $[49,50]$, clinical validation has not been done yet. This 
represent an important prerequisite to establish natural product-based cancer therapy in the future.

For Aloe-emodin, the range of genes with different functions is remarkably diverse. Genes operating in signal transduction, apoptosis, nucleic acid metabolism and other pathways were identified by COMPARE analysis. This gene expression profile resembles the molecular architecture of cell lines that have not been pretreated with Aloe-emodin. This experimental setting is characteristic for a phenomenon clinically known as inherent or primary resistance. While some tumors will respond to chemotherapy, others are non-responsive, although they have never been pretreated with anticancer drugs.

In addition to primary resistance, an initially sensitive tumor can acquire resistance upon repeated chemotherapy cycles, which was termed acquired or secondary resistance. Under laboratory conditions, it is possible to compare gene expression profiles of treated and non-treated cells. The resulting differentially expressed genes can be used to generate testable hypothesis on the molecular modes of action and determinants of resistance of cytotoxic compounds. There are numerous examples in the literature for the validity of this concept [51-54].

The results as well as the genes obtained by COMPARE and cluster analyses indicate that Aloeemodin acted by multiple mechanisms against cancer cells. Multi-specificity represents a typical feature of many - if not all - natural products [55]. Based on the microarray data of differentially expressed genes between treated and non-treated cells, we assumed that Aloe-emodin generates ROS, which leads to DNA damage and cell cycle arrest. As a consequence, the mitochondrial pathway of apoptosis is induced as shown by disruption of the mitochondrial membrane potential and annexin V/PI staining.

Findings of other authors confirm our point of view: Aloe-emodin induced DNA-damage in vitro [56-58]. In animal experiments, it inclined DNA damage after two oral application [38]. These data fit to the observed cell cycle disturbations (i.e., S- and G2/M-arrest) as well as apoptosis upon Aloe-emodin exposure [59].

In addition to the elucidation of mechanisms of action and determinants of resistance to Aloe-emodin, our molecular pharmacological data substantiate the therapeutic application of $R$. acetosella against tumors in traditional medicine.

Nevertheless, it should be pointed out that the traditional use of $R$. acetosella as anticancer remedy cannot be explained by Aloe-emodin alone and that presumably other phytochemicals contribute to the bioactivity of this plant. Several modes of action can be envisioned:

(1) One substance is the main active compound and other compounds in the plant support its actions, e.g. as solvent mediators.

(2) Several compounds reveal bioactivity against one or several therapeutic targets. The substances mutually supplement each other in additive or synergistic manner.
(3) The main compound reveals not only activity against diseased cells and tissues but also against normal tissues leading to side effects. Concomitant compounds in the plant dampen the side effects.

Based on the results of the present investigation, further analyses are warranted to clarify, which of these possibilities are realized in $R$. acetosella. This final goal is to understand the full bioactivity of this plant to utilize its full potential for rationale phytotherapy of cancer.

\section{MATERIALS AND METHODS}

\section{Plant material}

$R$. acetosella was collected from Camlidere (Ankara, Turkey) in May 2012. A voucher specimen has been deposited in the Herbarium of Faculty of Pharmacy, Hacettepe University, Ankara, Turkey (HUEF: 13005).

\section{General phytochemical procedure}

Normal phase column chromatography and reverse phase column chromatography were run on silica gel 60 (0.063-0.200 mm, Merck, Darmstadt, Germany) and RP18 silica gel (40-63 $\mu \mathrm{M}$, Merck, Darmstadt, Germany), respectively. Sephadex LH-20 (Sigma, Sweden) was used for separation of the compounds based on their molecular size. Thin layer chromatography (TLC) was applied on silica gel $60 \mathrm{~F}_{254}$ precoated plates (Merck, Darmstadt, Germany). The spots were observed using an UV lamp at 254 and $365 \mathrm{~nm}$, followed by spraying with $1 \%$ vanillin/ $\mathrm{H}_{2} \mathrm{SO}_{4}$ and then heating at $110^{\circ} \mathrm{C}$.

Nuclear magnetic resonance (NMR) spectra were recorded on an Avance III 600 (Bruker) using $5 \mathrm{~mm}$ probe heads at a temperature of $23^{\circ} \mathrm{C}$. The ${ }^{1} \mathrm{H}$ and ${ }^{13} \mathrm{C}$ chemical shifts were referenced to the residual/deuterated solvent (e.g., for MeOD, $\delta=3.31$ and $49.00 \mathrm{ppm}$ for $1 \mathrm{H}$ and $13 \mathrm{C}$ NMR, respectively) and reported in parts per million (ppm, $\delta)$ relative to tetramethylsilane (TMS, $\delta=0.00 \mathrm{ppm}$ ). Coupling constants $(J)$ are reported in Hz, and the splitting abbreviations used were: s, singlet; d, doublet; $t$, triplet; m, multiplet; br, broad; and combinations thereof. Highresolution masses (ESI) were recorded on a Q-ToF-Ultima 3 instrument (Waters) with LockSpray ${ }^{\mathrm{TM}}$ interface and a suitable external calibrant. Optical rotations were measured with a Perkin-Elmer 241 polarimeter at $589 \mathrm{~nm}$. Infrared spectra were recorded as FT-IR spectra on a Tensor 27 spectrometer (Bruker) using a diamond ATR unit and are reported in terms of frequency of absorption $\left(\mathrm{v}, \mathrm{cm}^{-1}\right)$.

\section{Extraction and isolation of natural substances}

Roots of $R$. acetosella (529.68 g) were dried on air, grinded and extracted with methanol $(10 \mathrm{~L} \times 7)$ at $40^{\circ} \mathrm{C}$ under reflux for $72 \mathrm{~h}$. The extract was filtered and evaporated under vacuum and $83.26 \mathrm{~g}$ crude 
extract was gained. We used normal phase silica gel column chromatography (SK), reverse phase column chromatography including vacuum liquid chromatography (VLC) or medium pressure liquid chromatography (MPLC) and Sephadex column chromatography with isocratic $\mathrm{CH}_{3} \mathrm{OH}$ elution (SPH) to isolate pure compounds.

Initially, the crude extract was processed by SK-1 gradient elution from $\mathrm{CH}_{2} \mathrm{Cl}_{2}: \mathrm{CH}_{3} \mathrm{OH}$ (95:5) to $\mathrm{CH}_{2} \mathrm{Cl}_{2}: \mathrm{CH}_{3} \mathrm{OH}: \mathrm{H}_{2} \mathrm{O}$ (60:40:4). Fraction (27-28) of SK-1 was further processed by SK-16 accompanied by $\mathrm{CH}_{3} \mathrm{COOC}_{2} \mathrm{H}_{5}: \mathrm{CH}_{3} \mathrm{OH}: \mathrm{H}_{2} \mathrm{O}$ gradient elution from $(100: 5: 2)$ to $(100: 17: 13)$. Fraction (10-14) of SK-16 was subjected to SPH-15. The obtained fraction (13-16) gained was re-conducted on SPH-16 to get fraction (1526 ), which was enriched with compound 1 . This fraction was subsequently applied to VLC consecutively to get fraction VLC-9/(16-17) as pure compound (Compound 1, $21.3 \mathrm{mg}$ ).

Similar purification steps as for compound 1were performed, until we obtained fractions of SPH-15. SPH15/(5-7) was applied to SPH-19. Fraction (7-11) from SPH-19 was subjected to VLC to obtain VLC-10/(15-16) as pure compound (Compound 2,10 mg).

Fraction 15-20 from SK-16 was run on successive SPH columns to get the fraction (8-13) from SPH-21. Subsequently, the fraction was processed by VLC-11 with $\mathrm{CH}_{3} \mathrm{OH}: \mathrm{H}_{2} \mathrm{O}(20: 80)$ isocratic elution. Then, the fraction (20-24) from VLC being virtually pure was finally applied to preparative TLC to yield completely pure compound (Compound 3, $12.4 \mathrm{mg}$ ).

The fraction SK-1/(35-36) as one of the first column fractions of the crude extract was run on SK-2 with the gradient elution of $\mathrm{CHCl}_{3}: \mathrm{CH}_{3} \mathrm{OH}: \mathrm{H}_{2} \mathrm{O}$ from $(80: 20: 2)$ to (61:32:7). SK-2/(6-12) was repeatedly applied to SK column chromatography until fraction SK-4/(1-2) was obtained. After subjecting this fraction to VLC with $\mathrm{CH}_{3} \mathrm{OH}: \mathrm{H}_{2} \mathrm{O}(60: 40)$ isocratic elution, we gained fraction (9-14) and applied the fraction to SPH1. Fraction (15-20) from SPH-1 was applied on another VLC with $\mathrm{CH}_{3} \mathrm{OH}: \mathrm{H}_{2} \mathrm{O}$ from (40:60) to (50:50) isocratic elution. VLC-2/(28-34) was gained as pure compound (Compound 4, $13.5 \mathrm{mg}$ ).

The identical protocol applied for compound 2 was conducted until getting fractions from VLC-10. VLC-10/ (80-82) was the pure compound (Compound 5, 3.6 mg).

The fraction SK-1/(23-24) as one of the first column fractions of the crude extract was applied on SK-17 accompanied with $\mathrm{CH}_{3} \mathrm{COOC}_{2} \mathrm{H}_{5}: \mathrm{CH}_{3} \mathrm{OH}: \mathrm{H}_{2} \mathrm{O}$ $(100: 17: 13)$ isocratic elution. Fraction (6-8) from SK17 was repeatedly applied to SPH chromatography until fraction (6-11) was obtained from SPH-26. After subjecting this fraction to VLC-13 accompanied by $\mathrm{CH}_{3} \mathrm{OH}: \mathrm{H}_{2} \mathrm{O}$ gradient elution from $(40: 60)$ to $(55: 45)$, fraction (33-51) from VLC-13 was subjected to another two rounds of SK column chromatography by using gradient elution of $\mathrm{CH}_{3} \mathrm{COOC}_{2} \mathrm{H}_{5}: \mathrm{CH}_{3} \mathrm{OH}: \mathrm{H}_{2} \mathrm{O}$ and
$\mathrm{CHCl}_{3}: \mathrm{CH}_{3} \mathrm{OH}: \mathrm{H}_{2} \mathrm{O}$, respectively in order to isolate SK20/(15-26) as pure compound (Compound 6, $13 \mathrm{mg}$ ).

The fraction SK-1/(23-24) as one of the first column fractions of the crude extract was applied to SK-17 accompanied by $\mathrm{CH}_{3} \mathrm{COOC}_{2} \mathrm{H}_{5}: \mathrm{CH}_{3} \mathrm{OH}: \mathrm{H}_{2} \mathrm{O}(100: 17: 13)$ isocratic elution. Fraction (4-5) was run on SPH-23 to get fraction (18-25) which was almost pure. Following fraction (18-25) from SPH-25, the yielded fraction, was applied to preparative TLC to obtain completely pure compound (Compound 7, $17.8 \mathrm{mg}$ ).

The same protocol was conducted, as we followed for compound 7, until we yielded the fractions of SK-17. Distinct from the fraction (4-5) of SK-17 for RAT-1, we applied the fraction (2-3) of SK-17 to preparative TLC to get the pure compound (Compound 8, $6 \mathrm{mg}$ ).

Initially, the crude extract was processed by SK-1 with gradient elution from $\mathrm{CH}_{2} \mathrm{Cl}_{2}: \mathrm{CH}_{3} \mathrm{OH}$ (95:5) to $\mathrm{CH}_{2} \mathrm{Cl}_{2}: \mathrm{CH}_{3} \mathrm{OH}: \mathrm{H}_{2} \mathrm{O}$ (60:40:4). The 33th fraction of SK-1 was applied to SK-2 accompanied by gradient elution of $\mathrm{CHCl}_{3}: \mathrm{CH}_{3} \mathrm{OH}: \mathrm{H}_{2} \mathrm{O}$ from $(80: 20: 2)$ to (61:32:7). SK-2/(22-24) was subjected to SK-6 with $\mathrm{CH}_{3} \mathrm{COOC}_{2} \mathrm{H}_{5}: \mathrm{CH}_{3} \mathrm{OH}: \mathrm{H}_{2} \mathrm{O}: \mathrm{HCOOH} \quad(100: 17: 13: 0.5)$ isocratic elution. SK-6/(2-6) was run on SK-7 accompanied with $\mathrm{CHCl}_{2}: \mathrm{CH}_{3} \mathrm{OH}: \mathrm{H}_{2} \mathrm{O}: \mathrm{HCOOH}$ gradient elution from $(70: 30: 3: 0.5)$ to $(61: 32: 7: 0.5)$. SK-7/(3-4) was applied to SPH-5 and fraction (23-49), which was almost pure, was applied to preparative TLC to obtain the completely pure compound (Compound 9, $13.5 \mathrm{mg}$ ).

The same steps performed to isolate compound 9 were conducted to obtain fraction (5-22) from SPH-5. SPH5/(5-22) was applied to MPLC followed by $\mathrm{CH}_{3} \mathrm{OH}: \mathrm{H}_{2} \mathrm{O}$ gradient elution from (45:55) to (100:0) as reverse phase chromatography. Fraction (45-80) was applied to preparative TLC and the mixture of two compounds was yielded (Compound 10, compound 11, $12 \mathrm{mg}$ ).

\section{Chemicals}

To have significant amounts for mechanistic studies available, anthraquinones were purchased from commercial sources. Aloe-emodin (purity (HPLC): min. 97 area \%) was obtained from TCI Deutschland GmbH (Eschborn, Germany) and was dissolved in DMSO. Emodin (purity after HPLC $\geq 90 \%$ ), physcion (purity after TLC $\geq 98 \%$ TLC) and rhein (technical grade) (from Sigma, Turkey) were also dissolved in DMSO. TNF- $\alpha$ was obtained from Biotrend Chemikalien GmbH (Köln, Germany). Doxorubicin was provided by the University Hospital of Johannes Gutenberg University (Mainz, Germany).

\section{Cell culture}

The cell lines used in the present work, their origins and maintenance conditions were previously reported [60-63]. In brief, drug-sensitive CCRF-CEM 
and multidrug resistant $\mathrm{P}$-glycoprotein-over-expressing CEM/ADR5000 leukemia cells, MDA-MB-231-pcDNA3 breast cancer cells and their transfectant subline MDAMB-231-BCRP clone 23, HCT116 $\left(p 53^{+/+}\right)$colon cancer cells and its knockout clone HCT116 (p53-- $)$, U87.MG glioblastoma multiform cells and their transfectant subline U87.MG $\triangle E G F R$ as well as HEK293 human embryonic kidney cells transfected with or without a cDNA for $A B C B 5$ were used. The human peripheral mononuclear cells (PMNC) were isolated from fresh blood samples of a healthy donor by using Histopaque ${ }^{\circledR}$ (Sigma-Aldrich, Taufkirchen, Germany).

Normal human peripheral mononuclear cells (PMNC) were isolated from fresh blood samples of a healthy donor using Histopaque ${ }^{\circledR}$ (Sigma-Aldrich). In brief, $6 \mathrm{~mL}$ blood were layered with $6 \mathrm{~mL}$ Histopaque ${ }^{\circledR}$ and centrifuged $(400 \times \mathrm{g})$ for $30 \mathrm{~min}$ at $4{ }^{\circ} \mathrm{C}$. The opaque interface containing lymphocytes and other mononuclear cells was transferred into a new tube and washed several times. Isolated PMNCs were kept in Panserin 413 medium (PAN-Biotech, Aidenbach, Germany) supplemented with $2 \%$ phytohemagglutinin M (PHA-M, Life Technologies, Darmstadt, Germany).

\section{Resazurin reduction assay}

Resazurin reduction assay was conducted to test the cytotoxicity of the compounds. This assay is based on the reduction of resazurin to resorufin by viable cells [64]. Non-viable cells do not show a blue staining because they lost their metabolic capacity which causing reduction of resazurin. Briefly, aliquots of $0.5 \times 10^{4}$ adherent cells which were allowed to attach overnight and $1 \times 10^{4}$ suspension cells per well were seeded in 96-well-plates with or without the addition of varying concentrations of the test substance to get a total volume of $200 \mu \mathrm{L} /$ well. After 72 $\mathrm{h}$ incubation and addition of resazurin (Sigma-Aldrich) for $4 \mathrm{~h}$, staining was measured by an Infinite M2000 ProTM plate reader (Tecan, Germany) using an excitation wavelength of $544 \mathrm{~nm}$ and an emission wavelength of 590 $\mathrm{nm}$. Each assay was independently performed for at least three times, with six parallel replicates each. The protocol has been recently reported [65]. Fifty percent inhibition concentrations $\left(\mathrm{IC}_{50}\right)$ represent the drug concentrations required to inhibit $50 \%$ of cell proliferation, which were fitted with nonlinear regression using GraphPad ${ }^{\circledR}$ Prism7.

\section{Protease viability marker assay}

The protease viability marker assay was performed to exclude the possibility that the cytotoxicity of Aloeemodin measured by the resazurin assay was artificially influenced by any non-intended interaction with Aloeemodin-induced ROS generation. The assay measures the protease activity within living cells. The protease activity is restricted to intact viable cells and is measured using a flourogenic, cell permeant, peptide substrate (glyxyl-phenylalanyl-aminoflourocoumarin; GF-AFC). The substrate enters intact cells, where it is cleaved by proteases to generate a fluorescent signal proportional to the number of living cells. Briefly, CCRF-CEM cells $\left(2 \times 10^{4}\right.$ cells/well $)$ were seeded in 96 well plate. Aloeemodin was added in a dose dependent manner $(0.001$ $-100 \mu \mathrm{M})$. After $72 \mathrm{~h}, 100 \mu \mathrm{L}$ of GF-AFC substrate (Promega, Madison, USA) were added to each well, cells were incubated for $30 \mathrm{~min}$ at $37^{\circ} \mathrm{C}$. Using Infinite M2000 Pro $^{\text {TM }}$ plate reader (Tecan, Crailsheim, Germany), the fluorescent intensity was measured at an excitation wavelength $400 \mathrm{~nm}$, and emitted light was collected at $505 \mathrm{~nm}$.

\section{Cell cycle analysis}

CCRF-CEM cells $\left(2 \times 10^{4}\right)$ were treated with 0.5 -, 1-, 2- or 4-fold $\mathrm{IC}_{50}$ of Aloe-emodin, respectively, for 6 , 24,48 or 72 h. The cells were collected, washed in PBS and fixed with ice-cold $96 \%$ ethanol. After washing the cells with PBS again, the cells were dissolved in PBS and stained with propidium iodide (PI, Sigma-Aldrich) at a final concentration of $50 \mu \mathrm{g} / \mathrm{mL}$ for $15 \mathrm{~min}$ in the dark. Cell cycle analyses were performed using a BD Accuri ${ }^{\mathrm{TM}}$ C6 Flow cytometer (Becton-Dickinson, Heidelberg, Germany) at $488 \mathrm{~nm}$ excitation wavelength, and emission was measured by a $610 / 20 \mathrm{~nm}$ band pass filter. All experiments were performed at least in triplicates. The protocol has been recently reported by us [66].

\section{Detection of early apoptosis and necrosis}

A commercial annexin V/PI detection apoptosis kit was used to detect early apoptosis and necrosis according to the manufacturer's instructions (Life Technologies, Carlsbad, CA, USA). Annexin V is a calcium-dependent phospholipid-binding protein, which binds to phosphatidylserine (PS). PS is predominantly located at the inner side of the plasma membrane under normal conditions and moves to outer surface of the membrane upon the onset of early apoptosis. This can be detected FITC-labeled annexin V. PI is a marker of late apoptosis and necrosis. We treated aliquots of $1 \times 10^{6}$ CCRF-CEM cells with 0.5-, 1-, 2- and 4-fold $\mathrm{IC}_{50}$ of Aloe-emodin for 48, 72 or $96 \mathrm{~h}$, respectively. After washing the cells with PBS, they were stained with annexin V/FITC at room temperature for 10-15 min. Subsequently, cells were washed again and stained with PI in the dark. Then, the results were analyzed by a BD Accuri ${ }^{\text {TM }}$ C6 flow cytometer at excitation wavelength $488 \mathrm{~nm}$ and emission wavelength $530 \mathrm{~nm}$ to record annexin V/FITC signals. The fluorescence of PI was detected at $488 \mathrm{~nm}$ excitation and was measured by a $610 / 20 \mathrm{~nm}$ band pass filter. At least three independent experiments were performed. [65]. 


\section{Detection of reactive oxygen species (ROS)}

$2^{\prime}, 7^{\prime}$-Dichlorofluorescin diacetate $\left(\mathrm{H}_{2} \mathrm{DCFH}-\mathrm{DA}\right.$, Sigma-Aldrich) is a cell-permeable non-fluorescent probe used to detect cellular ROS levels. In the presence of ROS, the compound is de-esterified intracellularly and converts into the highly fluorescent $2^{\prime}, 7^{\prime}$-dichlorofluorescein upon oxidation. Thus, it can be measured by flow cytometry [67]. CCRF-CEM cells were re-suspended in PBS and incubated for 30 min withH ${ }_{2}$ DCFH-DA at a concentration of $2 \mu \mathrm{M}$. After washing with PBS, the cells were treated with DMSO as negative control, $\mathrm{H}_{2} \mathrm{O}_{2}$ and doxorubicin as positive controls or varying concentrations of Aloeemodin $\left(0.5-, 1-, 2\right.$ - and 4-fold $\left.\mathrm{IC}_{50}\right)$ for $1 \mathrm{~h}$. The results were assessed by a BD Accuri ${ }^{\mathrm{TM}} \mathrm{C} 6$ flow cytometer (Becton Dickinson) using FL-1 the channel $(488 \mathrm{~nm}$ excitation). For each sample, $10^{4}$ cells were counted. The protocol has been recently reported by us [68].

\section{Comet assay}

The OxiSelect ${ }^{\mathrm{TM}}$ Comet Assay Kit (Cell Biolabs/ Biocat, Heidelberg, Germany) was used to detect DNA damage according to the manufacturer's instructions. CCRF-CEM cells treated with 1-, 2- and 4-fold $\mathrm{IC}_{50}$ of Aloe-emodin for $24 \mathrm{~h}$. Then, the cells were mixed with agarose and applied to OxiSelect ${ }^{\mathrm{TM}}$ Comet Assay slides. These slides including the embedded cells were treated with lysis buffer and alkaline solution. Subsequently, electrophoresis was performed on the slide with a voltage of $22 \mathrm{~V}$ for $30 \mathrm{~min}$ corresponding to $1 \mathrm{~V} / \mathrm{cm}$ of the electrophoresis chamber. These slides were washed with distilled water. After fixation with $70 \%$ ethanol, the slides were stained with by a fluorescent DNA binding dye [69].

Then, the slides were photographed by a fluorescence microscope (EVOSs FL Cell Image System, Thermo Fisher Scientific Waltham, USA) using a FITC filter with an excitation wavelength of $490 \mathrm{~nm}$ and emission at 520 $\mathrm{nm}$. At least 50 cells per image were randomly selected and analyzed with the OpenComet software (http://www. cometbio.org). Percentages of tail DNA, tail moment and olive moment were assessed as parameters for DNA damage. The statistical significance was determined by oneway ANOVA with Tukey's multiple comparison test.

\section{Measurement of mitochondrial membrane potential (MMP)}

The JC-1 Mitochondrial Membrane Potential Assay Kit (Cayman Chemical, Ann Arbor, MI, USA) was applied for the detection of MMP by flow cytometry according to the manufacturer's instructions. The cationic dye, 5, 5', 6, 6'- tetrachloro- 1, 1', 3, 3'- tetraethylbenzimidazolylcarbocy anine iodide (JC-1) enters the mitochondria and changes its fluorescent properties based on the aggregation of the probe. In healthy cells having high MMP, JC-1 forms complexes known as J-aggregates with intense red fluorescence. On the other hand, in cells with low MMP, JC-1 remains in its monomeric form showing green fluorescence [70]. Aliquots of $5 \times 10^{5}$ cells $/ \mathrm{ml}$ were treated with DMSO as negative control, doxorubicin as positive control or 1-, 2- or 4-fold $\mathrm{IC}_{50}$ of Aloe-emodin for 24 and $48 \mathrm{~h}$. A LSR-Fortessa FACS analyzer (Becton-Dickinson) was used to detect the J-aggregate form of JC-1 with an excitation wavelength of $535 \pm 20 \mathrm{~nm}$ and an emission wavelength of $590 \pm 20 \mathrm{~nm}$ as well as the monomeric form of JC-1 at excitation and emission wavelengths of 485 and $535 \mathrm{~nm}$, respectively. The results were analyzed by the FlowJo software (Celeza, Olten, Switzerland). $2 \times 10^{4}$ cells were counted for each experiment which were repeated in triplicate [71].

\section{Microarray gene profiling}

Total RNA was isolated by InviTrap Spin Universal RNA Mini kit (Stratec Molecular, Berlin, Germany) according to the manufacturer's instructions. The quality control of total RNA, probe labeling, hybridization, scanning and data analysis was performed in the Genomics and Proteomics Core Facility at the German Cancer Research Center (DKFZ, Heidelberg, Germany). Details have been previously described [72]. The Chipster software was used to filter the set of differentially expressed genes obtained from microarray hybridization (http://chipster.csc.fi/) with a $p$ value lower than 0.05 . These filtered genes with fold-changes of more than 1-fold were selected for Ingenuity Pathways Analysis Software (http://www.ingenuity.com/ Ingenuity Systems, Redwood City, CA, USA) to obtain profiles of genetic networks and signaling pathways. The protocol has been recently reported by us [73].

\section{COMPARE and hierarchical cluster analyses}

A panel of 60 cell lines from the National Cancer Institute (NCI), USA were used to perform COMPARE. Logarithmic $\mathrm{IC}_{50}$ values $\left(\log _{10} \mathrm{IC}_{50}\right)$ have been deposited at the NCI database (http://dtp.cancer.gov/databases_tools/default. $\mathrm{htm}$ ). The mRNA expression values of the NCI cell lines were determined via microarray analyses were deposited at the NCI website (http://dtp.cancer.gov/databasestools/default.htm) as well. These data were used to generate rank ordered lists of genes expressed in the NCI cell lines panel using COMPARE analyses [32]. Briefly, the selected genes of the NCI microarray database were ranked for similarity of its mRNA expression values to the $\log _{10} \mathrm{IC}_{50}$ values for Aloe-emodin..

Objects were categorized by determination of distances with regard to the closeness of betweenindividual distances to conduct hierarchical cluster analysis. All objects were assembled into dendrograms. Grouping of objects with similar properties provokes cluster formation. Distances of subordinate cluster branches to superior cluster branches serve as criteria for the closeness of clusters. Thus, objects with tightly related features were clustered closely, while separation 
of objects in the dendrogram increased with progressive dissimilarity. We applied the WARD method using the WinSTAT program (Kalmia, Cambridge, MA, USA). The protocol has been recently reported by us [74].

The distribution of cell lines sensitive or resistant to Aloe-emodin was calculated using the $\chi^{2}$ test. The $\chi^{2}$ test was performed to determine bivariate frequency distributions of pairs of nominal scaled variables. It was used to calculate significance values ( $p$-values) and rank correlation coefficients ( $R$-values) as relative measure for the linear dependency of two variables. This test was implemented into the WinSTAT program (Kalmia Co.). The $\chi^{2}$-test determines the difference between each observed and theoretical frequency for each possible outcome, squaring them, dividing each by the theoretical frequency, and taking the sum of the results. To perform the $\chi^{2}$-test, the median $\log _{10} \mathrm{IC}_{50}$ value of all cell lines tested for Aloe-emodin was used as cut-off to separate tumor cell lines as being "sensitive" or "resistant".

\section{Quantitative real-time polymerase chain reaction (qPCR)}

Primer sequences of $H H E X, M C M D C 2$ and $C R C P$ were designed using NCBI and GenScript Real Time PCR Primer Design (https://www.genscript.com/sslbin/app/primer) websites. DUSP6, HHEX, MCMDC2 and $C R C P$ primers were synthesized by Eurofins $M W G$ Operon (Ebersberg, Germany) and their sequence specificities were checked by NCBI Primer-Blast (http:// www.ncbi.nlm.nih.gov/tools/primer-blast). The reaction properties of primers were calculated by Eurofins genomics (https://www.eurofinsgenomics.eu/en/dna-rnaoligonucleotides/oligo-design-more/oligo-property-scan. aspx). The primer sequences were as follows: DUSP6, forward $\left(5^{\prime}-3^{\prime}\right)$ : CCTGAGGCCATTTCTTTCATAGA, reverse (5'-3'): GTCACAGTGACTGAGCGGCTAAT [75]; HHEX, forward: TCTACTCTGGAGCCCCTTCT, reverse: GGTTTTGACCTGTCTCTCGC; $M C M D C 2$, forward: TGCGGCTTCTAGACAGTTCA, reverse: GAGCTTGTTCTGATTCTGCG; CRCP, forward: GGGGAGAAGAAACATGGTGA, reverse: CCGTGGAGGAAATCTTTCAA. Total RNA was isolated by InviTrap Spin Universal RNA Mini kit (Stratec Molecular) according to the manufacturer's instruction. One microgram RNA was converted to cDNA using RevertAid H Minus First Strand cDNA Synthesis Kit (Thermo Scientific). The mRNA levels were analyzed by using of $5 \times$ Hot Start Tag EvaGreen ${ }^{\circledR}$ qPCR Mix (no ROX) (Axon Labortechnik, Kaiserslautern, Germany) and CFX384 ${ }^{\mathrm{TM}}$ Real-Time PCR Detection System (BioRad, Munich, Germany). RT-PCR was performed with an initial denaturation at $95^{\circ} \mathrm{C}$ for 10 second followed by 40 cycles including strand separation at $95^{\circ} \mathrm{C}$ for $15 \mathrm{~s}$, annealing at $62^{\circ} \mathrm{C}$ for $30 \mathrm{~s}$ and extension at $95^{\circ} \mathrm{C}$ for $1 \mathrm{~min}$. The GAPDH, HPRT1 and RLP13 genes were used as housekeeping genes. The expression data were normalized using Bestkeeper software [76]. Among the three housekeeping genes investigated, GAPDH was the most stable one. The regression analyses using Bestkeeper for $G A P D H$ revealed an R-value of 0.9. Therefore, GAPDH was used for normalization. Forward and reverse primer sequences of $G A P D H$ were TGAAGGTCGGAGTCAACGGATTTGGT for forward and CATGTGGGCCATGAGGTCCACCAC for reverse, respectively [77].

Furthermore, forward and reverse primer sequences of HPRT1 were AGATGTGATGAAGGAGATGGG for forward and ACCAAGGAAAGCAAAGTCTG for reverse as well as of RLP13A were TATGCTGCCCCACAAAACC for forward and TTTCTCTTTCCTCTTCTCCTCC for reverse, respectively.

The quantification method was done as follow:

$\Delta \mathrm{Ct}=\mathrm{Ct}$ gene test $-\mathrm{Ct}$ endogenous control.

$\Delta \Delta \mathrm{Ct}=\Delta \mathrm{Ct}$ sample $1-\Delta \mathrm{Ct}$ calibrator.

$\mathrm{RQ}=$ Relative quantification $=2-\Delta \Delta \mathrm{Ct}$.

The RQ is the fold-change compared to the calibrator (untreated sample, time zero, etc.). The calibrator has an RQ value of 1 . All samples were compared to the calibrator.

A RQ of 10 means that this gene is 10 times more expressed in sample $x$ than in the calibrator sample. A RQ of 0.1 means that the gene is 10 times less expressed.

\section{Abbreviations}

DTP, Developmental Therapeutics Program; GF-AFC, glyxyl-phenylalanyl-aminoflourocoumarin; IPA, Ingenuity pathway analysis; MMP, mitochondrial membrane potential; MPLC, medium pressure liquid chromatography; NCI, National Cancer Institute; PMNC, peripheral mononuclear cells; ppm, parts per million; SPH, Sephadex column chromatography; SK, silica gel column chromatography; qPCR, quantitative real-time polymerase chain reaction; ROS, reactive oxygen species; TLC, thin layer chromoatography; VLC, vacuum liquid chromatography.

\section{Author contributions}

Nadire Özenver performed the experiments and wrote the paper. Thomas Efferth supervised the project and wrote the paper. Mohamed Saeed assisted conducting the experiments and drawing the figures. L. Ömur Demirezer supervised the isolation of substances from $R$. acetosella.

\section{ACKNOWLEDGMENTS}

We are thankful to a 12-months stipend to N.Ö. from The Scientific and Technological Research Council of Turkey (TÜBITAK), scholarship 2214-A. 


\section{CONFLICTS OF INTEREST}

The authors declare that there is no conflicts of interest.

\section{REFERENCES}

1. Ferlay JS, Ervik M, Dikshit R, Eser S, Mathers C, Rebelo M, Parkin DM, Forman D, Bray F. Estimated cancer incidence, mortality and prevalence worldwide in 2012. Lyon, France: International Agency for Research on Cancer. 2013.

2. National Cancer Institute. https://www.cancer.gov/about cancer/understanding/statistics (accessed on 21.02.2017).

3. Efferth T. Resistance to targeted abc transporters in cancer. New York: Springer. 2014.

4. Efferth T, Grassmann R. Impact of viral oncogenesis on responses to anti-cancer drugs and irradiation. Crit Rev Oncog. 1999; 11:165-87.

5. Efferth T, Volm M. Pharmacogenetics for individualized cancer chemotherapy. Pharmacol Ther. 2005; 107:155-76.

6. Newman DJ, Cragg GM. Natural products as sources of new drugs over the last 25 years. J Nat Prod. 2007; 70:461-77.

7. Kuete V, Saeed ME, Kadioglu O, Börtzler J, Khalid H, Greten HJ, Efferth T. Pharmacogenomic and molecular docking studies on the cytotoxicity of the natural steroid wortmannin against multidrug-resistant tumor cells. Phytomedicine. 2015; 22:120-7.

8. Eyong KO, Kuete V, Efferth T. 10 - quinones and benzophenones from the medicinal plants of Africa. Medicinal plant research in africa. Oxford: Elsevier. 2013. pp. 351-91.

9. Seigler DS. Plant secondary metabolism. New York: Springer. 2012.

10. Zhang LS, Chang CJ, Bacus SS, Hung MC. Suppressed transformation and induced-differentiation of Her-2 neuuverexpressing breast cancer cells by emodin. Cancer Res. 1995; 55:3890-6.

11. Cichewicz RH, Zhang YJ, Seeram NP, Nair MG. Inhibition of human tumor cell proliferation by novel anthraquinones from daylilies. Life Sci. 2004; 74:1791-9.

12. Zhang L, Lau YK, Xia W, Hortobagyi GN, Hung MC. Tyrosine kinase inhibitor emodin suppresses growth of HER-2/neu-overexpressing breast cancer cells in athymic mice and sensitizes these cells to the inhibitory effect of paclitaxel. Clin Cancer Res. 1999; 5:343-53.

13. Srinivas G, Anto RJ, Srinivas P, Vidhyalakshmi S, Senan VP, Karunagaran D. Emodin induces apoptosis of human cervical cancer cells through poly(ADP-ribose) polymerase cleavage and activation of caspase-9. Eur J Pharmacol. 2003; 473:117-25.
14. Cha TL, Qiu L, Chen CT, Wen Y, Hung MC. Emodin downregulates androgen receptor and inhibits prostate cancer cell growth. Cancer Res. 2005; 65:2287-95.

15. Acevedo-Duncan M, Russell C, Patel S, Patel R. Aloeemodin modulates PKC isozymes, inhibits proliferation, and induces apoptosis in U-373MG glioma cells. Int Immunopharmacol. 2004; 4:1775-84.

16. Shieh DE, Chen YY, Yen MH, Chiang LC, Lin CC. Emodin-induced apoptosis through p53-dependent pathway in human hepatoma cells. Life Sci. 2004; 74:2279-90.

17. Lin S, Fujii M, Hou DX. Rhein induces apoptosis in HL-60 cells via reactive oxygen species-independent mitochondrial death pathway. Arch Biochem Biophys. 2003; 418:99-107.

18. Chen YC, Shen SC, Lee WR, Hsu FL, Lin HY, Ko $\mathrm{CH}$, Tseng SW. Emodin induces apoptosis in human promyeloleukemic HL-60 cells accompanied by activation of caspase 3 cascade but independent of reactive oxygen species production. Biochem Pharmacol. 2002; 64:1713-24.

19. Rao K, Ch S, Banji D. A study on the nutraceuticals from the genus Rumex. Hygeia J Drugs Med. 2011; 3:76-88.

20. Hartwell JL. Plants used against cancer. A survey. Lloydia. $1971 ; 34: 386-425$.

21. Vasas A, Orban-Gyapai O, Hohmann J. The genus Rumex: review of traditional uses, phytochemistry and pharmacology. J Ethnopharmacol. 2015; 175:198-228.

22. Leonard SS, Keil D, Mehlman T, Proper S, Shi XL, Harris GK. Essiac tea: scavenging of reactive oxygen species and effects on DNA damage. J Ethnopharmacol. 2006; 103:288-96.

23. Wegiera M, Smolarz HD, Bogucka-Kocka A. Rumex L. species induce apoptosis in 1301, EOL-1 and H-9 cell lines. Acta Pol Pharm. 2012; 69:487-99.

24. Duke JA. Handbook of biologically active phytochemicals and their activities. Boca Raton, Florida: CRC Press, Inc. 1992.

25. Đurđević L, Gajić G, Jarić S, Kostić O, Mitrović M, Pavlović P. Analysis of benzoic and cinnamic acid derivatives of some medicinal plants in Serbia. Arch Biol Sci. 2013; 65:603-9.

26. Fairbairn JW, El-Muhtadi FJ. Chemotaxonomy of anthraquinones in Rumex. Phytochemistry. 1972; 11:263-8.

27. Cooke MS, Evans MD, Dizdaroglu M, Lunec J. Oxidative DNA damage: mechanisms, mutation, and disease. FASEB J. 2003; 17:1195-214.

28. Norbury CJ, Zhivotovsky B. DNA damage-induced apoptosis. Oncogene. 2004; 23:2797-808.

29. Kroemer G, Reed JC. Mitochondrial control of cell death. Nat Med. 2000; 6:513.

30. Newmeyer DD, Ferguson-Miller S. Mitochondria: releasing power for life and unleashing the machineries of death. Cell. 2003; 112:481-90. 
31. Desagher S, Martinou JC. Mitochondria as the central control point of apoptosis. Trends Cell Biol. 2000; 10:369-77.

32. Paull KD, Shoemaker RH, Hodes L, Monks A, Scudiero DA, Rubinstein L, Plowman J, Boyd MR. Display and analysis of patterns of differential activity of drugs against human tumor cell lines: development of mean graph and COMPARE algorithm. J Natl Cancer Inst. 1989; 81:1088-92.

33. Wosikowski K, Schuurhuis D, Johnson K, Paull KD, Myers TG, Weinstein JN, Bates SE. Identification of epidermal growth factor receptor and c-erbB2 pathway inhibitors by correlation with gene expression patterns. J Natl Cancer Inst. 1997; 89:1505-15.

34. Xie QC, Yang YP. Anti-proliferative of physcion 8-O-betaglucopyranoside isolated from Rumex japonicus Houtt. on A549 cell lines via inducing apoptosis and cell cycle arrest. BMC Complement Altern Med. 2014; 14:377.

35. Wegiera M, Smolarz HD, Wianowska D, Dawidowicz AL. Anthracene derivatives in some species of Rumex L. genus. Acta Soc Botan Pol. 2007; 76.

36. Westendorf J. Anthranoid derivatives - general discussion. Adverse effects of herbal drugs 2: Berlin: Springer. 1993, pp. 105-18.

37. Pecere T, Gazzola MV, Mucignat C, Parolin C, Vecchia FD, Cavaggioni A, Basso G, Diaspro A, Salvato B, Carli M, Palù G. Aloe-emodin is a new type of anticancer agent with selective activity against neuroectodermal tumors. Cancer Res. 2000; 60:2800.

38. Nesslany F, Simar-Meintières S, Ficheux H, Marzin D. Aloe-emodin-induced DNA fragmentation in the mouse in vivo comet assay. Mutat Res. 2009; 678:13-9.

39. Liu K, Park C, Li S, Lee KW, Liu H, He L, Soung NK, Ahn JS, Bode AM, Dong Z, Kim BY, Dong Z. Aloe-emodin suppresses prostate cancer by targeting the mTOR complex 2. Carcinogenesis. 2012; 33:1406-11.

40. Hientz K, Mohr A, Bhakta-Guha D, Efferth T. The role of p53 in cancer drug resistance and targeted chemotherapy. Oncotarget. 2017; 8:8921-46. https://doi.org/10.18632/ oncotarget.13475.

41. Pluchino KM, Hall MD, Goldsborough AS, Callaghan R, Gottesman MM. Collateral sensitivity as a strategy against cancer multidrug resistance. Drug Resist Updat. 2012; 15:98-105.

42. Weinstein JN. Spotlight on molecular profiling: "Integromic" analysis of the NCI-60 cancer cell lines. Mol Cancer Ther. 2006; 5:2601-5.

43. National Cancer Institute. https://dtp.cancer.gov/databases tools/compare.htm (accessed on 07.12.2017).

44. Szakács G, Annereau JP, Lababidi S, Shankavaram U, Arciello A, Bussey KJ, Reinhold W, Guo Y, Kruh GD, Reimers M, Weinstein JN, Gottesman MM. Predicting drug sensitivity and resistance: profiling $\mathrm{ABC}$ transporter genes in cancer cells. Cancer Cell. 2004; 6:129-37.
45. Reinhold WC, Sunshine M, Liu H, Varma S, Kohn KW, Morris J, Doroshow J, Pommier Y. CellMiner: a webbased suite of genomic and pharmacologic tools to explore transcript and drug patterns in the NCI-60 cell line set. Cancer Res. 2012; 72:3499-511.

46. Abdelfatah SA, Efferth T. Cytotoxicity of the indole alkaloid reserpine from Rauwolfia serpentina against drugresistant tumor cells. Phytomedicine. 2015; 22:308-18.

47. Ooko E, Saeed ME, Kadioglu O, Sarvi S, Colak M, Elmasaoudi K, Janah R, Greten HJ, Efferth T. Artemisinin derivatives induce iron-dependent cell death (ferroptosis) in tumor cells. Phytomedicine. 2015; 22:1045-54.

48. Kadioglu O, Jacob S, Bohnert S, Nass J, Saeed ME, Khalid H, Merfort I, Thines E, Pommerening T, Efferth T. Evaluating ancient egyptian prescriptions today: anti-inflammatory activity of Ziziphus spina-christi. Phytomedicine. 2016; 23:293-306.

49. Fu Y, Kadioglu O, Wiench B, Wei Z, Gao C, Luo M, Gu C, $\mathrm{Zu} \mathrm{Y,} \mathrm{Efferth} \mathrm{T.} \mathrm{Cell} \mathrm{cycle} \mathrm{arrest} \mathrm{and} \mathrm{induction} \mathrm{of} \mathrm{apoptosis}$ by cajanin stilbene acid from Cajanus cajan in breast cancer cells. Phytomedicine. 2015; 22:462-8.

50. Zamani M, Sadeghizadeh M, Behmanesh M, Najafi F. Dendrosomal curcumin increases expression of the long non-coding RNA gene MEG3 via up-regulation of epi-miRs in hepatocellular cancer. Phytomedicine. 2015; 22:961-7.

51. Wesolowski R, Ramaswamy B. Gene expression profiling: changing face of breast cancer classification and management. Gene Expr. 2011; 15:105-15.

52. Tsao AS, Papadimitrakopoulou V. The importance of molecular profiling in predicting response to epidermal growth factor receptor family inhibitors in non-smallcell lung cancer: focus on clinical trial results. Clin Lung Cancer. 2013; 14:311-21.

53. Lin Y, Kazlova V, Ramakrishnan S, Murray MA, Fast D, Chandra A, Gellenbeck KW. Bone health nutraceuticals alter microarray mRNA gene expression: a randomized, parallel, open-label clinical study. Phytomedicine. 2016; 23:18-26.

54. Wu CF, Seo EJ, Klauck SM, Efferth T. Cryptotanshinone deregulates unfolded protein response and eukaryotic initiation factor signaling in acute lymphoblastic leukemia cells. Phytomedicine. 2016; 23:174-80.

55. Efferth T, Koch E. Complex interactions between phytochemicals. the multi-target therapeutic concept of phytotherapy. Curr Drug Targets. 2011; 12:122-32.

56. Chen YY, Chiang SY, Lin JG, Yang JS, Ma YS, Liao CL, Lai TY, Tang NY, Chung JG. Emodin, Aloe-emodin and rhein induced DNA damage and inhibited DNA repair gene expression in SCC-4 human tongue cancer cells. Anticancer Res. 2010; 30:945-51.

57. Lee HZ, Lin CJ, Yang WH, Leung WC, Chang SP. Aloeemodin induced DNA damage through generation of reactive oxygen species in human lung carcinoma cells. Cancer Lett. 2006; 239:55-63. 
58. Muller SO, Eckert I, Lutz WK, Stopper H. Genotoxicity of the laxative drug components emodin, Aloe-emodin and danthron in mammalian cells: topoisomerase II mediated? Mutat Res. 1996; 371:165-73.

59. Chen R, Zhang J, Hu Y, Wang S, Chen M, Wang Y. Potential antineoplastic effects of Aloe-emodin: a comprehensive review. Am J Chin Med. 2014; 42:275-88.

60. Kimmig A, Gekeler V, Neumann M, Frese G, Handgretinger R, Kardos G, Diddens H, Niethammer D. Susceptibility of multidrug-resistant human leukemia cell lines to human interleukin 2-activated killer cells. Cancer Res. 1990; 50:6793-9.

61. Doyle LA, Yang W, Abruzzo LV, Krogmann T, Gao Y, Rishi AK, Ross DD. A multidrug resistance transporter from human MCF-7 breast cancer cells. Proc Natl Acad Sci U S A.1998; 95:15665-70.

62. Kawanobe T, Kogure S, Nakamura S, Sato M, Katayama K, Mitsuhashi J, Noguchi K, Sugimoto Y. Expression of human ABCB5 confers resistance to taxanes and anthracyclines. Biochem Biophys Res Commun. 2012; 418:736-41.

63. Efferth T, Sauerbrey A, Olbrich A, Gebhart E, Rauch P, Weber HO, Hengstler JG, Halatsch ME, Volm M, Tew KD, Ross DD, Funk JO. Molecular modes of action of artesunate in tumor cell lines. Mol Pharmacol. 2003; 64:382-94.

64. O'Brien J, Wilson I, Orton T, Pognan F. Investigation of the Alamar Blue (resazurin) fluorescent dye for the assessment of mammalian cell cytotoxicity. Eur J Biochem. 2000; 267:5421-6.

65. Kuete V, Mbaveng AT, Nono EC, Simo CC, Zeino M, Nkengfack AE, Efferth T. Cytotoxicity of seven naturally occurring phenolic compounds towards multi-factorial drug-resistant cancer cells. Phytomedicine. 2016; 23:856-63.

66. Kuete V, Mbaveng AT, Sandjo LP, Zeino M, Efferth T. Cytotoxicity and mode of action of a naturally occurring naphthoquinone, 2-acetyl-7-methoxynaphtho[2,3-b]furan4,9-quinone towards multi-factorial drug-resistant cancer cells. Phytomedicine. 2017; 33:62-8.

67. Cossarizza A, Ferraresi R, Troiano L, Roat E, Gibellini L, Bertoncelli L, Nasi M, Pinti M. Simultaneous analysis of reactive oxygen species and reduced glutathione content in living cells by polychromatic flow cytometry. Nat Protoc. 2009; 4:1790-7.
68. Wu CF, Klauck SM, Efferth T. Anticancer activity of cryptotanshinone on acute lymphoblastic leukemia cells. Arch Toxicol. 2016; 90:2275-86.

69. Wu CF, Hong C, Klauck SM, Lin YL, Efferth T. Molecular mechanisms of rosmarinic acid from Salvia miltiorrhiza in acute lymphoblastic leukemia cells. J Ethnopharmacol. 2015; 176:55-68.

70. Reers M, Smith TW, Chen LB. J-aggregate formation of a carbocyanine as a quantitative fluorescent indicator of membrane potential. Biochemistry. 1991; 30:4480-6.

71. Wu CF, Efferth T. Miltirone induces G2/M cell cycle arrest and apoptosis in CCRF-CEM acute lymphoblastic leukemia cells. J Nat Prod. 2015; 78:1339-47.

72. Eberwine J, Yeh H, Miyashiro K, Cao Y, Nair S, Finnell R, Zettel M, Coleman P. Analysis of gene expression in single live neurons. Proc Natl Acad Sci U S A. 1992; 89:3010-4.

73. Wu CF, Seo EJ, Klauck SM, Efferth T. Cryptotanshinone deregulates unfolded protein response and eukaryotic initiation factor signaling in acute lymphoblastic leukemia cells. Phytomedicine. 2016; 23:174-80.

74. Ooko E, Kadioglu O, Greten HJ, Efferth T. Pharmacogenomic characterization and isobologram analysis of the combination of ascorbic acid and curcumin - two main metabolites of Curcuma longa - in cancer cells. Front Pharmacol. 2017; 8:38.

75. Domercq M, Alberdi E, Sanchez-Gomez MV, Ariz U, PerezSamartin A, Matute C. Dual-specific phosphatase-6 (Dusp6) and ERK mediate AMPA receptor-induced oligodendrocyte death. J Biol Chem. 2011; 286:11825-36.

76. Pfaffl MW, Tichopad A, Prgomet C, Neuvians TP. Determination of stable housekeeping genes, differentially regulated target genes and sample integrity: Bestkeeper-Excel-based tool using pair-wise correlations. Biotechnol Lett. 2004; 26:509-15.

77. Glare EM, Divjak M, Bailey MJ, Walters EH. Beta-actin and GAPDH housekeeping gene expression in asthmatic airways is variable and not suitable for normalising mRNA levels. Thorax. 2002; 57:765-70.

78. National Center for Biotechnology Information. https:// www.ncbi.nlm.nih.gov/omim (accessed on 24.05.2017).

79. Bioinformatics and Biological Computing Unit. http://www. genecards.org (accessed on 24.05.2017). 